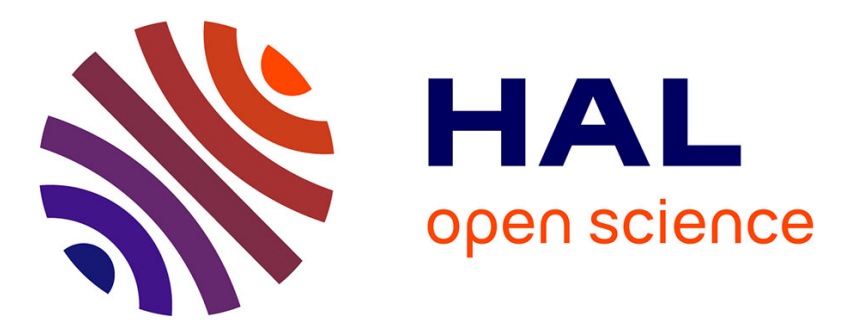

\title{
Criticisms of capitalism, budgeting and the double enrolment: Budgetary control rhetoric and social reform in France in the 1930s and 1950s
}

Nicolas Berland, Eve Chiapello

\section{- To cite this version:}

Nicolas Berland, Eve Chiapello. Criticisms of capitalism, budgeting and the double enrolment: Budgetary control rhetoric and social reform in France in the 1930s and 1950s. Accounting Organizations and Society, 2009, Vol. 54 (ISSUE 1), pp. 28-57. halshs-00365946

\section{HAL Id: halshs-00365946 \\ https://shs.hal.science/halshs-00365946}

Submitted on 5 Mar 2009

HAL is a multi-disciplinary open access archive for the deposit and dissemination of scientific research documents, whether they are published or not. The documents may come from teaching and research institutions in France or abroad, or from public or private research centers.
L'archive ouverte pluridisciplinaire HAL, est destinée au dépôt et à la diffusion de documents scientifiques de niveau recherche, publiés ou non, émanant des établissements d'enseignement et de recherche français ou étrangers, des laboratoires publics ou privés. 


\title{
Criticisms of capitalism, budgeting and the double enrolment: Budgetary control rhetoric and social reform in France in the 1930s and 1950s
}

\author{
Nicolas Berland ${ }^{\mathrm{a}}$, Eve Chiapello ${ }^{\mathrm{b}, *}$ \\ ${ }^{a}$ Université Paris-Dauphine, DRM, Place du Maréchal de Lattre de Tassigny, 75775 Paris Cedex 16, France \\ ${ }^{\mathrm{b}}$ HEC School of Management, 78350 Jouy-en-Josas, France
}

\begin{abstract}
This article is a contribution to the study of the spread of management innovations, methods and rhetorics. It particularly concerns the influence of ideological and political factors, which have so far mostly escaped in-depth study. In particular, we seek to understand to what extent a critique of society developed by social reformers can be a source of inspiration for managers, leading them to change their practices and experiment with new devices. Relying on the framework of historical change in management practices developed by Boltanski and Chiapello [Boltanski, L., \& Chiapello, E. (2005). The new spirit of capitalism. London: Verso (Translation of Le nouvel esprit du capitalisme, Paris: Gallimard, 1999)], we study the specific development of budgetary control in France, examined in the light of the general political and economic history of the 20th century. This framework simultaneously encompasses the dissemination of a new accounting practice, the transformation of capitalist institutions and mo des of regulation in a given period and country, and the programmatic discourses [Miller, P., \& Rose, N. (1990). Governing economic life. Economy and Society, 19(1), 131] associated with the historical move.

More exactly, what interests us is a double enrolment process. The business world promoters of budgetary control use the rhetorics of social reformers to present budgetary control as a solution to the economic and social problems of their time; conversely, social reformers promote budgetary control as a realistic, efficient tool that can change the world. Ultimately, a degree of alliance is possible around this management tool, although the extent to which the meanings each group attributes to its action are shared may remain unclear. Based on an analysis of the writings of budgetary control promoters of the 1930s and the 1950s, we show the close links between their discourse and the reforming ideas of their time, and how we can trace through this corpus the evolution of this kind of political rationalities [Miller, P., \& Rose, N. (1990). Governing economic life. Economy and Society, 19(1), 1-31] associated with governing and managing corporations we call the spirit of capitalism [Boltanski, L., \& Chiapello, E. (2005). The new spirit of capitalism. London: Verso (Translation of Le nouvel esprit du capitalisme, Paris: Gallimard, 1999)].
\end{abstract}

(C) 2008 Elsevier Ltd. All rights reserved.

\footnotetext{
* Corresponding author. Tel.: +331396794 41; fax: +33139 677086.

E-mail addresses: nicolas.berland@dauphine.fr (N. Berland), chiapello@hec.fr (E. Chiapello).
}

Accounting change and accounting innovation have become major themes for accounting research in recent years (Bjørnenak, 1997; Burns \& Scapens, 2000; Chua, 1995; Jones \& Dugdale, 
2002). Sociologically based research in management accounting using Foucauldian, Latourian or New Institutionalism approaches has been widely referred to in accounts of these changes (Baxter \& Chua, 2003). We adopt a sociological perspective in this paper, studying the double enrolment of social reformers' rhetorics and accounting innovations. Our work aims to answer three fundamental research questions: Where do management innovation and management rhetorics come from? How is it that certain rhetorics spread at certain times? How can we explain the changes over time in management discourses? This article proposes a theoretical framework and tests it against some parts of the history of budgetary control.

The originality of our approach lies in the emphasis placed on the role of social reformers and the dynamics of capitalism. We argue that capitalism may in certain circumstances, incorporate the critiques of the social reformers in order to regenerate. We use the term social reformers for actors in society who, upon encountering economic or social phenomena they deem regrettable or maybe even highly dangerous, simultaneously produce a critique of society, a diagnosis of the risks it is running, and proposals for reforms, regardless of whether these reforms are considered realistic or utopian. The reformers who become influential and whose opinions are listened to are rarely lone crusaders; generally they are part of a social movement, attend meetings of clubs or societies, organise conferences and courses to popularise their ideas, and have followers and propagators. A characteristic feature of such reformers - who can be seen as conveyors of political rationalities and programmes and as promoters of specific technologies (Rose \& Miller, 1992) - in this case budgetary control - is that they are not necessarily in a position of power at the beginning of the reform process. Often critical of the dominant groups and public policies of their time, they tend to position themselves as forces for opposition and/or proposals. But their ideas may be adopted by businesses or states, usually in order to overcome a difficult crisis. Their rhetoric thus finds itself transported to the very heart of the system against which it was produced, and their proposals put into practice. Their reflection gives birth to ideas for new devices, and brings about invention of new management practices or tools which avant-garde managers then experiment with. In this process of incorporation of criticism into the capitalist organisation, some members of the reforming social move- ments may gain access to positions of power, but ideas spread far beyond the actual actions of these social reformers, as the reforming proposals are also taken on board by avant-garde managers who are followed by a wide range of people.

We argue that the dynamic process of capitalism's incorporation of a critique is brought into operation by business managers who decide to change their practices based on the criticisms received and any associated recommendations, or political leaders who use the law or various specially created or reformed institutions to change the regulations governing business practices. The first steps taken by companies when incorporating a critique are typically taken by avant-garde managers who are interested in the ideas tossed around in reforming circles and may even themselves be part of those circles. It is often these managers' experiences that are later recounted, presented as examples, debated and imitated when the diffusion process is set in motion. This process will ultimately result in a morphological transformation of capitalism, enabling it to continue while simultaneously self-regenerating.

Such links between technologies and programmes have already been highlighted in research by Miller and O'Leary (1987, 1989, 1994), Miller and Rose (1990), Miller (1990) and Rose and Miller (1992). We add to this existing work a reflective analysis of the origins of political rationalities and programmes of government, and the way in which they are constructed. We aim to show that some of these ideas, which subsequently became very widespread, originated in the currents of criticisms of capitalism.. The case of budgetary control itself has never before been studied from this angle. Our article is based on an analysis of the discourses promoting budgetary control in France from the 1930s to the 1950s, based on two corpuses of texts. We concentrate on the ideas that surrounded declarations made about budgetary control, putting it into perspective in relation to economic and social problems at a national level, or considering it in relation to moral imperatives for the transformation of society. These discussions provide an insight into the ideological environment of the promoters of budgetary control.

From the late 1920s to the 1960s a group of accounting techniques developed in France, based on a complex of practices rooted in scientific management. Budgetary control is one of its tools, and developed alongside standard costing. "Budgetary control" presupposes: (1) the existence of a "budget", i.e. a set of forecast figures expressed in accounting 
language, covering the whole of the company's activity, and (2) the production of reports comparing the forecasts with what actually happened. Although standard costing can be a help in preparing forecasts - and is often discussed in the same writings as budgetary control, and attributed the same kind of sociopolitical advantages - both techniques developed in a loosely coupled relationship. The progress in France of these two innovations, which "render visible the inefficiencies" (Miller \& O'Leary, 1987, p. 241) differed: while budgetary control drifted fairly rapidly from discourse to practice, the drift was slower for standard costing. ${ }^{1}$ The reason for going into no further detail regarding the characteristics of budgetary control, ${ }^{2}$ is because its history is also the history of the debates over the "right way" to use it, which are themselves indissociable from the various "functions" attributed to the tool (Berland, 1999b; Burchell, Clubb, Hopwood, Hughes, \& Nahapiet, 1980; Ezzamel, 1994; Hopwood, 1978, 1983; Preston, Cooper, \& Coombs, 1992). We shall see that the meaning attributed to budgetary control changes through the period studied. Our work focuses on programmatic aspirations conferred on budgetary control, that is on management discourses and not on management practices as deployed within firms. However, particularly when a rhetoric accompanies the spread of a new management technique, we suggest that the study of discourses provides some information on changes in practices. In so far as discourses cognitively frame actors' interpretations of a management tool or practice, and in doing so they transform the practice itself, making it conform further to the predominant interpretation. This echoes the theories of Burchell et al. (1980), who showed the disconnection between the publicly stated roles of accounting and the practice of accounting, but also the importance of official roles in changing practices, accounting being "challenged and changed in the name of the roles it is seen as serving" (Burchell et al., 1980, p. 10).

The first part of this article is devoted to a presentation of our framework, together with a brief explanation of our working method. The second

\footnotetext{
${ }^{1}$ Maybe, as Zimnovitch $(1997,2001)$ maintains, because in the 1930s this technique found itself in competition with the French full cost method (of homogeneous sections).

${ }^{2}$ For example what are the intended uses of budgetary control reports, whether they are a basis for evaluation of the performance of an entity or its managers, whether the forecasts are global or broken down into components, with varying degrees of detail as regards the organisation's activities, or what is the amount of complementary non-financial information.
}

part will show how discussions of budgetary control were involved in the debate on social issues in the 1930s and 1950s, and how the idea of budgetary control changed between the two periods, in keeping with changes in this debate. The third part then further explores the productiveness of the theoretical framework put forward in The New Spirit of Capitalism (Boltanski \& Chiapello, 2005), in order to understand the evolution of business organisations between 1929 and 1960, as seen through the history of budgetary control. While the second section contains a point-by-point comparison of the ideas put forward by the reformers and the budgetary control promoters, the third section aims to describe the dynamics of the change in the representations.

\section{The dynamics of management rhetorics and their relationship with management change}

Previous studies have, like ours, taken an interest in management fashions (Abrahamson, 1996), the phenomena of institutionalisation (Barley \& Tolbert, 1997) and disinstitutionalisation (Oliver, 1991) of practices, and the rhetorics that support them (Watson, 1995; Zbaracki, 1998). We present some of these studies and show how they can be connected to the theoretical framework we use (Boltanski \& Chiapello, 2005), which we consider can expand on previous work by adding analyses of the role of reformers in management change.

\section{Management rhetorics and management change}

A number of studies aim to provide an account of the historical changes in management techniques with an interpretation of observed historical developments that goes beyond the simplistic and linear view of history that techniques have improved continuously. To achieve this aim, researchers have to draw up a history of the development of management, and an explanatory framework for this development. Barley and Kunda (1992), then Abrahamson (1997) share a view of history that distinguishes five management rhetorics since the 19th century: (1) welfare work; (2) scientific management; (3) human relations and personnel management; (4) systems rationalism; (5) organization culture and quality. They then analyse this sequence of periods as a cyclical phenomenon, arguing that a succession of cycles exists, in which "normative" theories (acting on employees' emotions and state 
of mind) alternate with "rational" theories (formally defining working processes). ${ }^{3}$

The historical framework adopted in this article is also structured around historical phases, but with longer durations, each encompassing a normative time and a rational time. We thus identify a first period running from the late 19th century to the crisis of the1930s, marked by both 'Welfare work' and 'Scientific management' ideas. A second period begins with the efforts made to emerge from the economic and social crisis of the 1930s, then to rebuild the world after the economic, moral and political crisis of the Second World War, extending to the late 1960s when the capitalist system encountered another crisis. This second period combines the 'Human relations and personnel management' ideas with 'Systems rationalism' ideas. Our third period opens with the crisis which started in 1968 as a crisis of meaning, a refusal of authority and rejection of mass society, and continued in the form of an economic crisis after the 1970s oil shocks. This period can be considered still ongoing: ideas concerning 'Organization culture and quality' are implemented, but new rational tools are developed in parallel, for instance new procedures for quality certification, and forms of control using information and communication technologies. Each period is associated with what we call a spirit of capitalism (Boltanski \& Chiapello, 2005).

Barley and Kunda (1992), and later Abrahamson (1997) put forward different explanations for the alternation between normative and rational theories. $^{4}$ However, both studies analyse the cycles essentially as the product of economic influence (growth and degree of innovation), even though they acknowledge that other factors may be taken

\footnotetext{
${ }^{3}$ By "normative theories", Barley and Kunda (1992, p. 364) mean "the idea that managers could more effectively regulate workers by attending not only to their behaviour but their thoughts and emotions". Normative theories are central in periods 1, 3 and 5. The same authors use "rational theories" $(1992,364)$ to refer to the rhetoric justifying "harsh discipline and even threats of violence by appealing to an individualistic ethic of success". According to their analysis, these rational theories are central in periods 2 and 4.

${ }^{4}$ First, cycles are said to succeed each other in response to performances considered mediocre (the performance gap theory). Second, these managerial cycles are thought to be constructed around economic cycles such as Kondratieff's pendulum theory: in growth phases, rational theories are supposed to supplant the normative theories presumed to dominate during when the cycle is on a downturn. Barley and Kunda (1992) give precedence to the pendulum theory, while Abrahamson (1997) considers these two explanatory theories as complementary.
}

into consideration (political and social relations, etc). Our own research acts on this intuition and seeks to reach a fuller understanding by emphasising these "other" factors of change. The history of management technologies (and the accompanying discourses) is related in our work with the overall history of capitalism, which cannot be summed up as a cyclical, reassuring history of alternation between "upward" and "downward" phases. Each crisis is new and unique, or at least has significantly distinctive features, and so is the way out of the crisis. History does not repeat itself in a neat and stylised way. The managerial forms adopted at a given period must be seen in relation to the institutional organisation of the economic system at a given time, and the way it is remodelled in each period by public policies and the efforts of all actors involved. Analysis of the history of management methods and rhetorics cannot be disconnected from an institutional analysis (Di Maggio \& Powell, 1983; Scott, 1995). What happens in companies and in the production of the normative discourses on management cannot be dissociated from the forms of economic regulations governing economic activity and the policies of public or private bodies - which are controlled to varying degrees by the political sphere that issue the regulations (Loft, 1986).

\section{Institutions, political rationalities and the "spirit of capitalism"}

Historical analysis of management devices should in our opinion take the political sphere into consideration. This is exactly what Miller does in his work with Rose and O'Leary. Rose and Miller (1992) propose to distinguish several levels in their study. First, there are the political rationalities, i.e. "the changing discursive fields within which the exercise of power is conceptualized, the moral justification for particular ways of exercising power by diverse authorities" ( $\mathrm{p}$. 175). The spirit of capitalism of a period in our analytical framework occupies the same place as these political rationalities, except that it primarily concerns the discursive field regarding how power is exercised in the enterprise, ${ }^{5}$ also encompassing the definition of the enterprise itself, its general operating rules and its role in society. The spirit of capitalism has a moral form, like any political rationality,

\footnotetext{
${ }^{5}$ Miller and Rose (1992), following the work of Michel Foucault, seek to reformulate the question of "the State" as "an investigation of the problematics of government".
} 
Table 1

Three spirits of capitalism

\begin{tabular}{|c|c|c|c|}
\hline & $\begin{array}{l}\text { First spirit end of } 19 \text { th } \\
\text { century-1930s }\end{array}$ & Second spirit 1940s-1970s & Third spirit since 1980 \\
\hline \multirow{4}{*}{$\begin{array}{l}\text { Characteristic features } \\
\text { of the economic } \\
\text { organisation }\end{array}$} & Small family firms & Managerial firms & Network firms \\
\hline & Bourgeois capitalism & Big industrial companies & Internet and biotech \\
\hline & & Mass production & Global finance \\
\hline & & States economic policy & Varying and differentiated productions \\
\hline $\begin{array}{l}\text { Periods defined by } \\
\text { Barley and Kunda } \\
\text { (1992) }\end{array}$ & $\begin{array}{l}\text { 1. Welfare work; } 2 . \text { Scientific } \\
\text { management }\end{array}$ & $\begin{array}{l}\text { 3. Human relations and } \\
\text { personnel management } 4 \text {. } \\
\text { Systems rationalism }\end{array}$ & 5. Organization culture and quality \\
\hline \multirow[t]{3}{*}{$\begin{array}{l}\text { What is the promise of } \\
\text { fairness? }\end{array}$} & $\begin{array}{l}\text { Meritocracy valuing loyalty } \\
\text { and respect of conventional } \\
\text { proprieties, and in an } \\
\text { apparent contradiction, } \\
\text { successes in market } \\
\text { competition situations }\end{array}$ & $\begin{array}{l}\text { Meritocracy valuing } \\
\text { effectiveness }\end{array}$ & $\begin{array}{l}\text { New form of meritocracy valuing mobility, } \\
\text { ability to nourish a network, etc }\end{array}$ \\
\hline & & Management by objectives & \\
\hline & & & $\begin{array}{l}\text { Each project is an opportunity to develop } \\
\text { one's employability: more employability if } \\
\text { more mobility }\end{array}$ \\
\hline \multirow[t]{2}{*}{$\begin{array}{l}\text { What is the promise of } \\
\text { security? }\end{array}$} & $\begin{array}{l}\text { Based on personal property } \\
\text { and relationships, charity } \\
\text { and paternalism }\end{array}$ & $\begin{array}{l}\text { Based on long term planning, } \\
\text { life long careers and welfare } \\
\text { state }\end{array}$ & For the mobile and the adaptable \\
\hline & & & $\begin{array}{l}\text { Companies will provide self-help resources } \\
\text { to enhance the ability to manage oneself }\end{array}$ \\
\hline \multirow[t]{4}{*}{$\begin{array}{l}\text { What is the promise of } \\
\text { stimulation? }\end{array}$} & $\begin{array}{l}\text { Freedom from local } \\
\text { communities progress }\end{array}$ & Career opportunities & No more authoritarian chiefs \\
\hline & & $\begin{array}{l}\text { Access to power positions } \\
\text { Effectiveness possible in } \\
\text { "freedom countries" }\end{array}$ & Fuzzy organisations \\
\hline & & & Innovation and creativity \\
\hline & & & Permanent change \\
\hline
\end{tabular}

determining the ideals in whose name the governing and managing of corporations is articulated. Any spirit of capitalism also paints a moral portrait of man perfectly well-adjusted to the enterprise of his time, stating his qualities, and the qualities that the system esteems and rewards: we say that it incorporates a response to anxiety over the fairness of the capitalist process. Therefore, a first set of arguments included in the spirit of capitalism of one time invokes the notion of fairness, explaining why capitalism is coherent with a sense of justice, and how it contributes to the common good.

A second set of arguments describes the forms of security that are supposed to be available to those who are involved, both for themselves and for their children. The last dimension focuses on what is presented as stimulating or exciting about an involvement with capitalism - in other words, how this system can help people to achieve fulfilment, and how it can generate enthusiasm. The rhetorical con- tent of the spirit of capitalism, i.e. these three categories of arguments, ${ }^{6}$ alters over time. Nevertheless, we consider that at any period the type of political rationality that is the spirit of capitalism must offer responses - albeit varying responses - to the three dimensions of fairness, security and stimulation.

The table below summarises the three spirits of capitalism that have succeeded each other since the later 19th century, and the phases in the history

\footnotetext{
${ }^{6}$ The spirit of capitalism can be seen as a set of justifications along these three dimensions (fairness, security, stimulation) in order to improve involvement in the capitalist process. In the theoretical framework we use, capitalistic accumulation requires commitment from many people, although few have any real chances of making a substantial profit and it is unrealistic to think including these people by force (working to survive) is all that is needed. One of the essential aspects of this involvement is the ability to give "meaning" to one's actions: this meaning goes beyond the mere idea of generating profit, and is supplied by what is called here the spirit of capitalism.
} 
of management that are assumed by this analysis. For each period, we show the argumentative content in terms of fairness, security and stimulation (see Table 1).

In the same way as the political rationalities discussed by Rose and Miller (1992), the spirit of capitalism also incorporates an epistemology and is formulated in a distinctive idiom. Thus, in each period, the management discourse has its own specific vocabulary and concepts, which help contemporaries to conceive the enterprise and its success factors.

The second level of analysis proposed by Rose and Miller is the level of governmental technologies, i.e. "the complex mundane programmes, calculations, techniques, apparatuses, documents and procedures through which authorities seek to embody and give effect to governmental ambitions" (Rose \& Miller, 1992, p. 175). "These 'technologies of government' seek to translate thought into the domain of reality, and to establish 'in the world of persons and things' spaces and devices for acting upon those entities of which they dream and scheme" (Miller \& Rose, 1990 , p. 8). This level is where we encounter management techniques and tools, such as budgetary control, which can also be analysed as central instruments for accomplishing the integration of the spirit of capitalism into business management practices. This explains why the management literature is considered a major receptacle for the spirit of capitalism of a given period. ${ }^{7}$

A history of management rhetorics and management tools thus requires a history of change in political rationalities, programmes of government and governmental technologies. Miller and his coauthors used this general framework to analyse various developments in management practices. Each time, they sought to reconstitute the discursive environment and programmes that fostered the spread

\footnotetext{
${ }^{7}$ Management literature comprises here all the normative texts, mainly written by consultants in the recent period, which particularly promote certain methods of organisation and certain "new" management practices. Boltanski and Chiapello (2005) show that at a given period, there is no infinity of ways to describe the "new high performance organisation" or the "organisation of the future": on the contrary, the models appear to converge around a small number of proposals which influence the spirit of the time. They based their efforts (as Weber and Sombart had done previously) on texts that provide moral education on business practices. In their study, this meant two bodies of work from the field of management studies: one from the 1960s; and one from the 1990s (each representing around 500 pages and 50 texts).
}

of a given management practice. Miller's (1991) study of the development of discounted cash flow procedures as a management tool in the 1950s, and the work by Miller and O'Leary (1987) relating talk of "national efficiency" and the early 20th century eugenist ideologies to the development of standard costs in the UK are good examples (see also Miller \& O'Leary, 1989, 1994). ${ }^{8}$ The approach taken by Burchell, Clubb, and Hopwood (1985) to the enthusiasm for value added in the 1970s is another example of this type of study, which aims to place the development of a management practice in the context of broader ideological debates.

What we propose to do in this article is to associate this approach with hypotheses on the origins of the ideas that emerge at a given moment in history. Where do these ideas come from to structure political rationalities and programmes of a period, eventually fostering the development of certain governmental technologies? This is where the framework developed by Boltanski and Chiapello (2005) can be useful.

\section{The framework of change in The New Spirit of Capitalism}

One major characteristic of this work is the role it attributes to criticisms of capitalism ${ }^{9}$ in producing changes in corporate practices and related ideolo-

\footnotetext{
${ }^{8}$ Miller and O'Leary (1989) show that the concepts of organisational authority presented by American writers of management literature from 1900 to 1940 were in keeping with the USA's political culture, and evolved with the debates in the political arenas. In particular, the 1929 crisis and its consequences are seen as a time of significant challenge to previous models of authority. This crisis led to a new management literature represented by the writings of Mayo and Barnard. In a further paper, Miller and O'Leary (1994) resituated the development of Activity-based costing and empowerment practices in the USA in the context of the 1980s American decline against Japan, and related to the discursive field of "New Economic Citizenship".

${ }^{9}$ Two types of criticism that have developed since the 19th century have been examined by Boltanski and Chiapello (2005). The first is what the authors call the "social critique". Here the emphasis is on inequalities, misery, exploitation, and the selfishness of a world that stimulates individualism rather than solidarity. Its main vector has been the labour movement. The second form of criticism, the "artistic critique", first emerged in small artistic and intellectual circles, and stresses other characteristics of capitalism. In a capitalist world, it criticises oppression (market domination, factory discipline), the massification of society, standardisation and pervasive commodification. It vindicates an ideal of liberation and/or individual autonomy, singularity and authenticity (Chiapello, 1998).
} 
gies. These criticisms are produced by social reformers and the social networks in which they participate. Their output is of course theoretical, aiming to diagnose problems, draw attention to situations considered negative, propose modifications, etc, but also practical, with the implementation of various campaigns belonging to what Tilly (1986) calls the "repertoires of collective action" (propaganda, training courses, demonstrations, strikes, boycotts, etc). In general, the management practices in existence at a given time, especially those presented as "the best practices", greatly depend on the type and virulence of the criticism levelled at them. Some of the transformations undergone by capitalism since May $1968^{10}$ can thus be analysed as a clever integration of the critiques of the 1970s and their demands for autonomy, creativity, more authentic interpersonal relationships, etc. Similarly, it is suggested that the transformations in progress over the period covered by this article result partly from the integration and adaptation of a certain number of proposals originally formulated by the labour movement, denouncing inequalities, poverty and exploitation.

Criticism plays several roles in the change process. First, it may produce ungovernability, a situation which encourages changes of method, particularly for business managers, in order to regain the capacity to govern. It also produces ideas, with the essential part of the reforming vision tending to concentrate on the problematic aspects

\footnotetext{
${ }^{10}$ The theoretical framework used as a basis here was initially developed to propose an interpretation of changes in business management methods in France from the post-May 1968 years. In May 1968, France underwent a major period of social unrest, marked by student demonstrations with suspension of lectures, occupation of the Sorbonne university and barricades in Paris' Latin quarter, and also by largescale workers' strikes all over France. These events led to the famous Grenelle agreements between employers and unions, under the auspices of the State, intended to end the insurrectional situation. In fact, the social unrest continued throughout the following decade, albeit to a lesser degree, centred on a critique of consumer society, with demands for greater liberty - including sexual liberty - experiments in worker autonomy with workers taking control of certain factories, and the beginnings of the ecological movement. The 1970s also saw a revival of the Marxist critique of exploitation and mass production, with particular interest in the Maoist and Yugoslav variations on "real socialism". This social agitation and its underlying themes were in fact shared by most developed countries over the period, although the most intense moments did not always coincide in time. May 1968 is the French landmark for what can be analysed as a global crisis of governability in western countries.
}

revealed. Some of these ideas will be taken on board and integrated into management practices for one or more of the following reasons: (1) because while satisfying the criticism they also serve profit, (2) because they provide a means of motivating people in a change process (even if the change is decided on for reasons other than the pressure exerted by the criticism), (3) or because this is the only way to silence criticism when it is persistent and inventive, and its virulence is beginning to undermine employee motivation and cause disorganisation in the enterprise. It can thus be said that a successful critique is fated to be taken over and adapted.

According to this approach, the ideas that were to arrive to construct new political rationalities concerning the economy's operation came from criticism of capitalism. Their ideas are more widely heeded when the economy is going through a major crisis, as in the 1930s or 1970s. The advantage of criticisms of capitalism is that, often ahead of others, they identified the contradictions and problems generated by the way the economy operates. They may also have fed reflection on possible remedies and analyses of the causes of difficulties. They thus present themselves as existing reservoirs of reforming ideas as and when necessary. In periods of great change, such as the years marking the transition from one spirit of capitalism to another, the ideas originating in the critical movements are enrolled to serve the reform of capitalism. They can be used to promote new management devices. Their supporters even occasionally suggest using a particular technology to facilitate this transition. The tool is reassuring, offering ways to grasp a problem and solutions. It may be called on independently without people necessarily being committed to the overall reform project. It is as if to engage more people, particularly more business managers, in change, the reformers had to propose tools and technologies which in themselves can "enrol" people without requiring a moral commitment to the cause (Callon \& Law, 1982; Callon, 1986; Latour, 1987). Additionally, it has been observed that certain promoters of management tools, particularly the consulting firms whose objective is to sell new approaches to businesses, sometimes adopt social reformers' rhetoric and vocabulary to increase the success of the tools they are promoting. In the case studied in this article - budgetary control - the ideas germinated in scientific management circles were taken over by the reforming groups of the 1930s. They were introduced into the plans for economic reform with the 
purpose of organizing the economy to avoid ever experiencing another 1930s-style crisis.

A two-way takeover of ideas is thus going on: (1) takeover by the social reformers of the "budgetary control" tool attracting the attention of business managers, in order to promote their way of organizing the economy - budgetary control as a Trojan horse for social reform; and (2) takeover by the promoters of budgetary control of the social reformers' ideas and the bright future they want to build, in order to bring in the tool they recommend, which finds itself being attributed virtues not only of efficiency but also of moral values - social reformism as an aid in constructing the legitimacy and ideological desirability of the budgetary control tool.

\section{Sources, corpus and working methods}

The history of budgetary control in France, the UK and the US has attracted substantially less attention than the history of cost calculation. It has often been hypothesised that Europe followed the example of US businesses, and that the development of budgetary control essentially dated from the end of the Second World War (see for example Ashton, Hopper, \& Scapens, 1995 for the UK, Cossu, 1986 for France). But more searching studies have shown that the situation in Europe was in fact fairly similar to the situation in the US. ${ }^{11}$ Research by Berland and Boyns (2002), Boyns (1998), Miller and O'Leary (1987), Parker (2002), Solomons (1952), Quail (1996), and Walsh and Stewart (1993), for instance, have shown that budgetary control dated from at least the 1930s in both countries.

For France, three historic phases can be identified in the development of budgetary control. The first more or less covers the decade of the 1930s, starting with the International Budgetary Control Conference held in Geneva by the Institut International d'Organisation Scientifique $d u$ Travail $(\text { IIOST })^{12}$ in 1930 . The conference's view of budgetary control was tinged with the rationalist thinking

\footnotetext{
${ }^{11}$ For the history of budgetary control in the US, see Chandler (1962, 1977), Chandler and Deams (1979), Johnson and Kaplan (1987), Kaplan (1984) and also research by Fleischman (2000), Fleischman and Tyson (2007) and Tyson (1992).

12 A direct translation would be "International Institute for Scientific Management", but the English name for the organisation was the International Management Institute (IMI). At the time of the conference, the director was Lyndall Urwick.
}

of the Taylorian engineers promoting it, with the accent above all on planning and technical difficulties. The second phase takes us to the end of the 1950s. In this phase, budgetary control was developing in an environment of postwar reform and the construction of the Fordist compromise (Aglietta, 1976; Boyer \& Mistral, 1978). Although it had not lost its rationalist nature, budgetary control was now being attributed other characteristics, such as humanising the economy and encouraging decentralisation within enterprises. The third phase covers all of the 1960s, and sees the arrival in force of discussions on motivation in the workplace. The emphasis is during this last period on use of the budget as a target to be achieved, and budgetary control as a means of motivation and performance evaluation $^{13}$ (Mc Arthur \& Scott, 1970; Taboulet, Meyer, \& Sallan, 1966).

This article covers the first two phases only. Most of the documents referred to for the second phase date from the 1950s, a much more homogeneous period in terms of history and ideology, when the uncertainties of wartime had disappeared and the postwar ideological battles had led to a new way of understanding and governing the economy (Kuisel, 1981). In any case, the wartime period was a "slack period" for introduction of budgetary control systems in businesses.

For the purposes of the various analyses, we studied both the history of budgetary control and the economic (Carré, Dubois, \& Malinvaud, 1972), social and political context (Boltanski, 1982; Kuisel, 1981) surrounding that history. Whereas primary sources (archives and contemporary documents) were used to describe the history of budgetary control (Berland, 1998, 1999a; Berland \& Boyns, 2002), a simple review of the existing literature was the basis for our examination of the reforming ideas with which we shall attempt to demonstrate budgetary control is linked. We thus based our work on research by historians and sociologists who have preceded us in the field (Amoyal, 1974; Boltanski, 1982; Braudel \& Labrousse, 1979; Cotta, 1984; Kuisel, 1981; Moutet, 1997), and highlighted the ideological continuity between the thinking of certain pioneering groups in the 1930 s and what was to

\footnotetext{
13 The seminal research by Argyris (1952) prefigures this third period, which in the academic world gave rise in the 1960s to a broad stream of academic literature on motivation, human behaviour and budgeting.
} 
become the predominant new ideology concerning the economy in the postwar period.

These studies show a parallel between the increasing adoption of budgetary control and the popularity of the ideas put forward by the 1930s reformers. However, we also need to demonstrate that this is more than mere coincidence, and that the promotion of budgetary control used the newly emerging economic ideology as a support (Lemarchand \& Le Roy, 2000). This requires sources that could indicate a link between the major social and economic issues of a period and budgetary control: we use public writings of budgetary control promoters. We show that they tend to adopt as their own some of the criticisms expressed in by social reformers. In the case of budgetary control, the promoters drew their arguments from the effervescence of ideas thrown up by seekers of alternatives to the marketled order in the 1930s (Kuisel, 1981). Two corpuses of around 30 texts were gathered, one concerning the 1930s and the other the 1950s (see Appendix). They consist of public writings that accompanied the development of budgetary control (textbooks, articles, conference papers, etc) (see Table 2). From these documents we selected extracts taking a more general look at the development of budgetary control, with reference to the main political and social issues debated in the relevant period.

The texts selected are by authors who are central to each of the two periods (recurring authors who are highly active promoters of budgetary control, or often cited) and significant in terms of size (writings longer than one page). The importance of the chosen extracts calls for two remarks. First, in terms of volume, the set of extracts containing programmatic elements is small compared to the total sum of purely technical extracts, which are longer and more detailed: the social and political commentaries are often found in forewords, prefaces, introductions and conclusions of articles and books with the body of texts being mainly technical. In terms of social significance, however, the selected texts are important, all the more so as an underlying political rationale common to all can be identified. Table 3 contains some figures indicating the extent to which the corpus source texts are representative. It shows that our corpus is far from marginal, being an extract from a body of publications representing between $37 \%$ and $41 \%$ of the references we were able to access, and between $16 \%$ and $27 \%$ of all references traced for the 2 periods.

These two corpuses were treated as follows: our main objective was to highlight the economic and social problems identified by the authors in discussing budgetary control, and the specific or more general solutions recommended to connect those ideas to the period's reforming currents. The quotations in this article are taken from this thematic reading. As is still the case today, the discourse on efficiency and the technical rationale is rarely the only dis-

Table 2

Main sources of evidence

\begin{tabular}{ll}
\hline Aspects studied & Main sources \\
\hline $\begin{array}{l}\text { Economic context } \\
\text { History of reforming ideas }\end{array}$ & $\begin{array}{l}\text { Braudel and Labrousse (1979), Carré et al. (1972) and Kuisel (1981) } \\
\text { Amoyal (1974), Boltanski (1982), Cotta (1984), Dard (1999), Kuisel } \\
\text { (1981) and Moutet (1997) }\end{array}$ \\
$\begin{array}{l}\text { The double enrolment (reforming ideas adopted by budgetary } \\
\text { control promoters and the budgetary control tool adopted by } \\
\text { social reformers) }\end{array}$ & $\begin{array}{l}\text { Two corpuses of texts specifically collected for the article consisting } \\
\text { of articles, conferences, lectures, and extracts from textbooks }\end{array}$ \\
$\begin{array}{l}\text { History of budgetary control. The evolution of practices in } \\
\text { companies }\end{array}$ & $\begin{array}{l}\text { Company archives studied in former research Berland (1998, } \\
\text { 1999a) and Berland and Boyns (2002) }\end{array}$ \\
\hline
\end{tabular}

Table 3

Representativeness of the corpus

\begin{tabular}{|c|c|c|}
\hline & $1930-1939$ & 1949-1959 \\
\hline $\begin{array}{l}\text { Total number of public texts on budgetary control identified for } \\
\text { the decade concerned }\end{array}$ & 200 & 128 \\
\hline Number of texts found in French libraries & 87 & 85 \\
\hline Number of references in the corpuses: & $\begin{array}{l}33 \text { ( } 7 \text { books and } 26 \\
\text { articles) }\end{array}$ & $\begin{array}{l}35 \text { ( } 16 \text { books or reports and } 19 \text { articles or } \\
\text { communications) }\end{array}$ \\
\hline
\end{tabular}


course to be found in texts promoting new management practices. It is generally inserted into a history reconstructed for rhetorical purposes, explaining that the world has changed and that the new issues faced by businesses require new practices or the implementation of a new instrument (Boltanski \& Chiapello, 2005).

This explains why the reader may encounter grandiose flights of lyricism talking of the wellbeing of humanity. One example comes from the lecture given at the Sorbonne in 1958 by Jean Benoit, the then managing executive of Pechiney, orchestrator of the implementation of budgetary control within the company and a tireless campaigner for the tool (see below). He ended his address to students in the following words: "You are all familiar with a foreign poet's reflection that we need a sort of "redemption of utilitarian man by artistic man". I sincerely believe that this expression is out of date, I believe the time has come to unite all men of good will in this country, whatever their origins, whatever their training, in order, as one of our workmen currently studying to become a foreman says: "to build together a common work with a view to constructing a better world". We hypothesise in this article that this nontechnical type of argument put forward by promoters of budgetary control can be explained by the links between the authors of these texts and the configurations of ideas conveyed more broadly by reforming movements.

\section{Budgetary control as part of the social debates in the period 1930-1950}

We first present the people, networks and channels that spread budgetary control (Section 'Promoters of budgetary control and their relationships with the reforming networks'). We shall see that several promoters of budgetary control are also involved in the work of reforming think-tanks and can thus be considered as much reformers as promoters of budgetary control. This is first-level evidence in support of our double enrolment hypothesis.

We then (Section 'The economic and social problems evoked by social reformers and promoters of budgetary control') describe the social and political problems the authors of our corpus deemed relevant to mention in writings on budgetary control. This can be considered a first, and fairly common, level of enrolment. In these extracts, the authors attribute historical importance to budgetary control by presenting it as a solution to contemporary issues.
There is no indication as yet that they have more broadly adopted the ideas of the reforming movements of their time: admittedly, they identify the same problems, but do they have the same general solutions? Section 'Reforming currents' sets out to answer this question. With reference to historians of ideas, we describe the reforming currents of the time known to have been at the source of socio-economic solutions implemented during the " 30 glorious years". We then show that these solutions are also present in the texts of our corpus. This is a much deeper level of enrolment, since certain promoters of budgetary control in our corpus make explicit reference to the reforming ideas of their time.

Finally (Section 2.4), we show how the definition of budgetary control evolved over the period in coherence with the spirit of capitalism, which itself interacted with the programmatic aims of the reforming movements, as it is impossible to separate the technical from the social, the former being totally impregnated with the latter.

\section{Promoters of budgetary control and their relationships with the reforming networks}

Four types of channel enabled the promoters of budgetary control to develop their ideas: journals, congresses, books and professional associations. These channels can be monitored individually through the 1930s. After 1945, there are too many for individual consideration, but we attempt to provide a brief description in contrast to the previous period.

\section{Journals, congresses and books}

Some journals were very active on the question of budgetary control: up to 1940, Mon Bureau published 22 articles on the subject, Organisation 29, Méthodes 14, Le Commerce 9, L'Usine 8 and La Comptabilité 5. A large number of other journals also covered the issue occasionally (Berland, 1998). After 1945, there was some continuity in publications with writings by authors who were already active before the war, published in the same journals, sometimes after name changes and mergers. ${ }^{14}$

\footnotetext{
14 Gaston Commesnil, for instance, an author of the 1930s, continued his work to keep accountants informed with the publication of one article in 1955 and two in 1956 in the journal Orga-Comptabilité.
} 
Congresses were also a forum for discussion: the first and the most important of these was held in 1930 in Geneva by the IIOST (Institut International d'Organisation Scientifique du Travail $)^{15}$ and was entirely devoted to budgetary control. Almost all the main actors for development of budgetary control in the 1930s took part in this congress. At least six other congresses contained presentations on budgetary control (Berland, 1998). After 1945, many meetings and events were organised, well illustrated by those attended by Jean Benoit (see Appendix), an executive at Pechiney (see below for a short biography).

Three books particularly merit attention for the 1930s. The first significant publication was by Dr Ludwig in 1930. As far as we know this is the first book in French on budgetary control. The second landmark book is by Satet (1936). This work is unique for two reasons: the personality of its author (see below for a short biography) and its content. Satet describes many true-life cases, and his bibliography lists most publications on budgetary control released in a large number of countries. No subsequent work ever equalled this level of documentation. The third remarkable work of the 1930s must be the book published by Mareuse (1938), who takes a more conceptual approach with less emphasis on convincing his readership, which no doubt explains the lack of any concrete examples.

In the postwar period, Paul Loeb of Alsthom published a two-volume book on budgetary control in 1956, presenting his own experience in educa-

\footnotetext{
${ }^{15}$ Present among the experts was McKinsey, the author of a 1922 book entitled Budgetary Control which became an important reference. The other speakers all came to share their practical experiences in budgetary matters, making the conference a meeting of practitioners. 258 persons registered for the conference: 44 were Swiss, 39 German, 35 French, 33 British and 23 of other nationalities. However, in the event only 197 were able to attend, including 31 Frenchmen. The attendees were given extensive documentation, including Anglo-American works but also several French documents. The Frenchmen included P. de Berc (Cie des Forges de Chatillon, Commentry et NeuvesMaisons), G. Delmas (member of the board of the printing firm Delmas, Chapon et Gounouilhon), H. Fayol (Fayol's son and a member of the board for Organisation économique moderne), M. Lacoin (general secretary of Citroën), P. Levy (management attaché for French national railways), A. Antoine (general manager of Strasbourg electricity), J. Milhaud (Head of Industrial organisation at the employers' federation CGPF), T. de Saint-Pulgent (general manager of Grands Magasins du Printemps), R. Satet (Head of the Industrial organisation department at the sectorial employers' federation UIMM), J. de Vilmorin (manager of Vilmorin-Andrieux et Cie, grain merchants).
}

tional form. Some new works marked this period. Jean Parenteau (1945) began a long series of publications that were landmarks in the development of the discipline. The proportion of books by teachers began to grow; the tone began to change. Examples and descriptions of pioneers' experiences became rarer, while a more general, more conceptual discourse on budgetary control practices gained ground.

\section{Professional associations}

Various professional groups played an acknowledged role in the spread of budgetary control. What is particularly interesting about them for our purposes is that they were also identified by the historians of their time as hubs of activity for the reforming imagination, as the place where each period's great reformers were meeting and exchanging ideas (Boltanski, 1982; Kuisel, 1981). Some authors in our corpus belong to these associations or think tanks, and some of the writings we study were published by those groups.

One such group was the CNOF, Comité National de l'Organisation Française, created by the merger between the Fayolian Centre d'Etudes Administratives formed in 1919 and the Taylorian Conférence de l'Organisation Française launched in late 1920 (Dard, 1999, p. 28). There were major tensions in the CNOF during the 1930s as a result of the crisis; its members argued fiercely over the line to take: whether to extend the organisation's activities to broad questions of society, or to restrict attention to the organisation of labour. Due to this very argument, the CNOF was a highly fertile breeding ground for ideas. Many authors in our corpus belonged to the $\mathrm{CNOF}$, and published articles on budgetary control in its journal, the Bulletin $d u$ CNOF. T. de Saint-Pulgent for example, Manager of Printemps department stores, where he introduced budgetary control, was a member. So was Jean Benoit, mentioned earlier, and Jean Coutrot, who dominated the whole prewar period, as he was active in most clubs and associations of the time and ideas circulated between them through him (Dard, 1999). After 1945, the CNOF continued to publish the bulletin launched in the 1930s for distribution to businesses and managers. All in all, the CNOF published no less than 39 documents on budgetary control between 1930 and 1963. It was also a training centre: by 1950, 20,000 engineers and foremen had followed evening classes organised by the CNOF (Boltanski, 1982, p. 189). 
Another active group was the CEGOS (Commission Générale d'Organisation Scientifique du travail), which became a well-known management consulting firm after the war and was led by Octave Gelinier (propagator in the 1960s of Management by Objectives, a complement to previous budgetary control practices). Originally, the CEGOS was formed in 1926 by the business employers' organisation CGPF (Confédération Générale de la Production Française) (Dard, 1999, p. 105). It was through the CEGOS that the future French full cost method (of homogeneous sections) developed by Emile Rimailho (published in 1928), who is also one of the authors of our corpus, came into being (Lemarchand, 1998). In the 1930s, the CEGOS organised several managers' meetings, many on the theme of budgetary control. After the war, the CEGOS continued its efforts to spread budgetary control through information meetings, but also branched out into training (Boltanski, 1982, p. 189). It set up the Hommes et Techniques journal and publishers, providing an opportunity for new actors to express opinions in what was already an old organisation. Among the published authors were Jean Parenteau (1949), who wrote a first article on budgetary control, and Claude Charmont (1952) who discovered "a new man in the company: the management controller". The CEGOS also continued its work through seminars. The most important, "Budgetary control: 6 French cases" (CEGOS, 1953) took place from May 5th-7th 1952 and was attended by many of the authors included in our corpus. The CEGOS published a total of no less than 91 documents on budgetary control between 1930 and 1964.

The very powerful employers' organisation Union des Industries Métallurgiques et Minières (UIMM) must also be mentioned. The head of its industrial organisation departments was no other than R. Satet, a pillar of the CNOF and also author of over 20 publications on budgetary control. In the early part of his career, Satet himself introduced budgetary control to the printing firm Imprimeries Delmas. A total of 15 UIMM publications were dedicated to budgetary control between 1930 and 1962 .

After the war, as part of the reconstruction effort, specific measures were taken to improve productivity in French companies and make up for France's "backward" situation. The General Planning Commission (Commissariat Général au Plan) became an important venue for meetings and debates. A working party on productivity was formed there in 1948, chaired by Jean Fourastie under the General Planning Commission. Subsequently a provisional productivity committee (Comité provisoire de la productivite) was set up in 1949, then the AFAP (Association Française pour l'Accroissement de la Productivité - French association for increased productivity) in 1950. To help the French "bring things up to standard", the Americans on the Marshall Plan Mission in France proposed that missions of company heads and unionists should visit the USA. One of the AFAP's main functions was to organise these missions, of which 450 took place (between 1950 and 1953) involving more than 4000 members, company managers, engineers, cadres (approximately 45\%), union representatives (approximately 25\%), top-ranking civil servants, economists, psychologists and sociologists (approximately 30\%) (Boltanski, 1982, p. 157ff; Kuisel, 1981, p. 262ff). The actual audience reached by these productivity missions is still a subject of debate between historians of this period. At least ten mission reports discussed the issue of budgetary control.

\section{The central role of certain authors}

In consulting the large number of publication sources mentioned above, it is impossible not to be struck by the central importance of some authors, who are encountered in various capacities.

One example is Jean Benoit, already mentioned several times, who can be considered one of the most important sources on budgetary control in the postwar years. He was an industrialist who had quite a significant lecturing activity. A graduate of the Ecole des Mines in Saint-Etienne, he joined AFC (one of the companies making up Pechiney) at the age of 26 (Cailluet, 1995). Four years later, he was the director of the Argentière plant, where he had been remarked in 1932 for his good performance in terms of production costs. A member of the French national management committee CNOF in the 1930s, he worked with Clark to establish budgetary control at Pechiney. From 1939, he managed the industrial organisation department in charge of reorganising the company. At the time of his sudden death in 1962, he was the company's general secretary. In parallel to his brilliant career at Pechiney, he had an important public life, teaching at the Ecole Nationale d'Administration, the Ecole de Guerre and the INSEAD. He was a founder member of the management control institute ICG - Institut de contrôle 
de gestion, and the research centre for company managers CRC (Centre de recherche et d'études des chefs d'entreprise) at Jouy en Josas. He also represented Pechiney at the French national employers' association CNPF, and was a member of the accounting standards board CNC (Conseil National de la Comptabilité). He was the author of many publications and without a doubt one of the founding fathers of budgetary control in France.

Robert Satet is another central character, whose focus on budgetary control dates from the 1930 Geneva congress. In 1927, he was a member of the Taylor Society, and in the same period he was involved in the creation and leadership of the CNOF. From 1930, he was the Head of the Scientific Management department at the UIMM, a powerful branch of the employers' organisation CGPF. According to the October 1936 issue of the Bulletin $d u$ CNOF, Satet was Head of the legal department of the Eastern France Foundry and Mines committee (Comité des Forges et Mines de fer de l'est de la France). He was also a lecturer at the EOST (Ecole d'Organisation Scientifique du Travail), a school influenced by the CNOF (Boltanski, 1982, p. 189; Collective, 1965), at Louvain University in Belgium, and at France's Ecole Nationale Supérieure des PTT. He presented case studies on budgetary control to the business administration training centre CPA (Centre de Perfectionnement à l'Administration des affaires), and released at least one publication through the CEGOS in 1942. Finally, these skills were directly placed at the service of companies through consulting activities. He was very open to international views and travelled, probably several times, to America where he visited local firms and examined their management system (Satet, 1942). He turned all these contacts and experiences to the collective benefit, with no less than 57 publications over the period 1926-1958. Many of these publications concern budgetary control. His major work is his book of 1936, which concerns precisely that technique.

Paul Loeb of Alsthom provides a further example of these avant-garde managers, acting as a liaising agent or intermediary between the different worlds: the world of in-firm management practices and techniques, and the worlds of socio-political ideals and social reform in reforming groups. Loeb, a graduate of France's prestigious higher education establishment, the Ecole Polytechnique, brought budgetary control to Alsthom (one of the pioneer- ing firms) in the 1930s, in conjunction with Auguste Detoeuf. ${ }^{16} \mathrm{He}$ was involved in the work of the CEGOS and the CNOF, and in 1956 published a dense two-volume review whose preface sets out the author's social ideals.

The central role in the spread of budgetary control played by professional associations participating in thought on reform during the 1930s (which would give rise to ideas implemented after the war), and by the avant-garde managers who came into contact with the ideas debated there, is an initial reflection of what we have called the "double enrolment" of budgetary control and social reform. It is very difficult in certain authors' work to separate what relates to their professional interest in a management practice they wish to promote from what relates to their hopes of building a better world through that practice.

After this general overview of the places and people central to the spread of budgetary control, we can legitimately focus our discussion on a limited number of writings mainly derived from those sources (Table 4).

We now analyse the content of the writings collected, beginning our exploration by addressing the socio-political challenges mentioned by our authors in texts that are all designed to promote budgetary control. This is a first level of magnification of their issues and enrolment, as major economic and social problems, nothing less, are what budgetary control is supposed to be able to help solve.

The economic and social problems evoked by social reformers and promoters of budgetary control

The people who developed budgetary control in France thought it could provide the answer to several problems under debate during the period. Three types of problem were discussed in reforming cir-

\footnotetext{
16 A fellow graduate of the Ecole Polytechnique which he entered in 1902, Detoeuf was the first president of Alsthom from 1928 to 1940. He was very open to modernist currents and in 1936 gave a famous speech to the X-Crise group (which was central to the reforming ideas of the period) entitled 'The end of the free market' (La fin du Libéralisme). He was also one of the founders of the journal Les Nouveaux Cahiers formed to campaign for a single, compulsory union bringing together employees and employers under corporatist ideas. But Detoeuf is no doubt best known for his collection of aphorisms written at the end of the 1930s, Propos d'O.L. Barenton, confiseur(The words of O.L. Barenton, confectioner). (Kuisel, 1981).
} 
Table 4

Central sources of budgetary control promotion

\begin{tabular}{llll}
\hline Books & Congresses and events & Journals & Organisations and professional associations \\
\hline Satet (1936) & Geneva, IIOST (1930) & Mon bureau & CNOF \\
Rimailho (1936) & & Bulletin du CNOF & CEGOS \\
Loeb (1956) & Jean Benoit's Lectures & Hommes et Techniques & Commissariat au Plan \\
CEGOS (1953) & (1950s) & (CEGOS) & (General Planning Commission), \\
Parenteau (1959) & & & AFAP- (Productivity Missions) \\
\hline
\end{tabular}

cles. (1) First, economic problems. The depression and the resulting social problems lay at the core of thinking in the 1930s, and still preyed on people's minds after the war. In addition to these issues, the post-1945 period had to face the problems of rebuilding a country worn out by war. (2) Second, there are moral problems, both before the war because the economic system is considered inhumane, and after the war due to the Fascistic drift of the Vichy government, and collaboration with Nazi power by certain factions of the French elite. (3) Finally, the threatening presence of the Soviet Union and an active workers' movement spurred on the search for a third way between the free-market economy, accused of having caused the crisis and the associated tragic social and political consequences, and State socialism.

We now look more closely at these issues that preoccupied the reformers of the period, and show that the literature on budgetary control echoed those concerns. To "sell" budgetary control, the authors in our corpus go further than simply listing its advantages in terms of economic efficiency at individual firm level; they also present it as a more general solution to the problems encountered by the French economy on condition it is relatively widespread, thereby re-shaping capitalism and enabling it to endure through self-regeneration, in keeping with the "third way" plan. Budgetary control thus appears as the central management tool, actualizing in practice the second spirit of capitalism, which was to emerge from the period's historical turmoil.

\section{Reforming the economy to avoid ever experiencing another such crisis}

The major source of preoccupation in the 1930s was of course the economic depression, which came late to France but nevertheless had a lasting impact on the country (Braudel \& Labrousse, 1979). This situation opened the way for strong criticism of the free market economy, ${ }^{17}$ which was accused of sowing disorder and creating an uncontrollable, unpredictable situation. In continuation of this diagnosis, the social reformers took economic reform as their primary objective. The industrialists' instinctive reaction was to form cartels which destroyed almost all competition. Some considered this a temporary development until market mechanisms could come back into operation, while others saw it as a new way of organising the economy so as to make it controllable. Rationalisation, careful, scientific study of production, and development of plans, particularly at industry sector level, were also seen as means of taming the market's destructive mechanisms.

The desire to reform the economy so that no such crisis could ever happen again is clear in the output of the budgetary control promoters of the 1930s. Pulvermann (1930) resituated budgetary control in this effort to control capitalism: "the budget should be defined as a search to plan and take measures to use all the serious data obtainable. In this way, we can distinguish and limit the speculative aspects of capitalism". Schmidt (1930) also thought that budgetary control would be a guard against future crises. "The development of the budget concept, particularly the long-term investment budget covering whole decades, is a response by the capitalist economy to the reproach first expressed long ago by representatives of the socialist economy, that it lacks foresight in the event of crises, which can only be avoided by such a method".

\footnotetext{
${ }^{17}$ Self-adjusting economic mechanisms appeared to have gone off the rails, and many observers, including Detoeuf, could not accept mass employment as the cost of modern economic adjustment. J. Coutrot, for example, complained: "There is a kind of deep-seated ferocity among these economic anarchists... typical of the recluse who washes his hands of human suffering and accepts and even applauds the operation of impersonal mechanisms that crush others" (quoted by Kuisel, 1981, p. 106).
} 


\section{National reconstruction}

Present from the 1930s onwards, the desire to establish a renewed economic system was mingled after the war with the imperative of national reconstruction. In the late summer of 1944, France found itself in a critical situation, much more difficult in fact than in 1919. An intensive investment policy was decreed, partly to the detriment of consumption. Low-cost production in massive quantities was also necessary to meet the needs for basic products rapidly. The French economy was on course for industrialisation by forced march.

A Keynesian-style growth-based economic policy was adopted. In contrast to the prewar Malthusian policies, it was founded on productivity gains achieved through Taylorism, and fairly shared between employers and employees, a mode of expansion considered Fordist by the regulation theorists (Aglietta, 1976; Boyer \& Mistral, 1978). US aid to European countries contributed to this reconstruction, but came with a certain number of structural reform demands attached. For the US, securing capitalism was important in this Europe where the Soviet grip had suddenly tightened. This external aid also required organisation to distribute it as best appropriate to current and future needs. To oversee the whole operation, a major planning effort began, involving French businesses. They sent representatives to talks with ministers for joint preparation of five-year plans. Planning thus became a language shared by business and the State. ${ }^{18}$ The productivity missions were part of this great project. There was an intensive propaganda campaign to support the productivity drive and the American example.

The first chapter of the accountants' mission report (OECCA, 1951) goes into great detail on the characteristics of the modern US enterprise, and the other chapters are devoted to various aspects of US firms' organisation and accounting techniques, particularly budgetary control. This first

\footnotetext{
${ }^{18}$ In contrast to a bureaucratic approach where needs are decided "at the top", in Jean Monnet's mind the aim was to associate the interested parties in order to acquire persuasive force. To identify the country's needs, a new national statistics office (INSEE) was set up to replace the former Statistique Générale de France (SGF) (Desrosières, 1998; Volle, 1977). The construction of national accounting is part of the same movement. The story has been told by the actors involved, in Fourquet (1980). Their experiences give a fairly good idea of the desire for reform at the time, and its tentative trial-and-error progress.
}

chapter strikes up the Fordist creed of the time: "High salaries", "mass production" and "production lines" are presented as early as page 8 as the pillars of the new economic organisation. The report stresses that "American employers consider that if they are to survive in a free economy, it is their responsibility to develop productivity while at the same time increasing total wages paid to blue-collar workers and guaranteeing job security. These general ideas are commonly expressed in the industrial and commercial communities, as well as in the universities, where the professors cooperate in the development of a modern philosophy of the industrial world."

\section{Recovery from the moral disorder}

In the post-war world, the desire to reform the economic system was accompanied by another priority: to recover from the "moral disorder" of the Third Republic and the Vichy government. As early as 1944, "the psychological climate in which economic reform occured was one of struggle. What began as an international war against Nazism increasingly became a civil war against Vichy and its supporters. The internal enemy, in economic terms, which was held heavily responsible for the defeat of 1940 and accused of being the mainstay of collaboration, was capitalism in general and the trusts in particular." (Kuisel, 1981, p. 188). There was a need to "build a better, or more moral, institutional life". This would involve a break from the IIIrd Republic, but also the Vichy government, considered "stained with national disgrace". What was required was "transcending liberalism, which had brought egotism, disorder, and backwardness under the republic, and destroying corporatism, which had ended in subjugation under Petain. Alongside the "hardline" republic would be an organised, yet free, economy dedicated to human dignity, economic equality, growth and the national interest" (Kuisel, 1981, p. 188).

The question of the moral rebuilding of society even found its way into texts on budgetary control: what budgetary control would foster was not only a better economic system, but also a more moral, humane system. In his book published in 1956, for instance, Loeb stated that: "It is not an exaggeration to claim that a genuine budgetary humanism has been born. (...) Man wants to control the forces which for so long have enslaved him. Through budgeting, he intends henceforth to direct the economy, put all the resources of nature at his service". Loeb again, speaking to CEGOS (1953) declared that budgetary control "is inseparable from the profound social 
preoccupations, since production is made for men, not men for production: the enterprise must endeavour to guarantee stability of employment for its personnel, to free them from the constant worries of employees, their fear of having no work, to avoid periods when they are overburdened with overtime being followed by short-time rationing of work."

Jean Benoit (1954), at a conference, raised several themes related to this new economic humanism, with explicit reference to budgetary control: "the aim is not only to provide economic subsistence and fairness in form, but to foster the fulfilment of individual initiatives;" "man does not live on bread and wages alone, but on aspirations and ideals;" "The company manager must not only be a constructor of products, but also and perhaps above all a constructor of men."

The search for a "third way" and a new form of cooperation between employers and employees

As early as the 1930 s, social reformers began to search for a "third way" between economic liberalism and state socialism. The main concern in the 1930s for employers, whether progressives or not, was to find a solution to the failure of capitalism and the development of socialism, which was seen as ideologically unacceptable. The arrival in power in 1936 of the Front Populaire and its nationalisation programme only made the need for an alternative solution all the more glaring. The period of crisis was also a time when the conflict of interests between employers and employees, theorised by Marxism, became more obvious and more worrying. This intensified the search for new forms of cooperation between employers and employees. Of course that preoccupation was nothing new (it is found for example in the writings of F.W. Taylor and more generally in the Fayolian and Taylorian movements), but budgetary control was seen as able to make a contribution. Its promoters reformulated Taylor's idea that "rational study" could bring about progress in employer-employee collaboration and a move towards fairer division of the value created.

Emile Rimailho (1936) explained how budgetary control is connected with scientific management in this intended collaboration: "the study and elementary preparation of work was where supervisors learned about working in collaboration; budgetary control is where managers learn about working in collaboration". Edmond Landauer (1930) explained at considerable length that analysis of variances from budget was "the only rational form of employee profit sharing", because "budgetary control of costs provides every participant in production with an exact budget for the part of the task that is his. Going over budget or staying within budget depends only on him, his efforts and his intelligence". (...) Therefore, with no fear of ever making an error, everyone can be attributed a percentage of the saving. (...) Many industrialists know that high salaries increase the purchasing power of the masses, and are useful for industry prosperity. However, they are afraid to grant them, for fear of increasing costs. The system of granting bonuses for savings on budgeted allowances removes this fear, since wage increases are inexorably associated with falling costs (...). In giving concrete expression to the interests of job providers and job takers, budgetary control is thus not only an instrument for economic prosperity, but also (maybe first and foremost!) a means of ensuring peaceful industrial relations." Furthermore, "Based on scientifically established standards [budgetary control] can reward each person's efforts according to merit, and provides a fair, practical solution to the controversial problem of access to a fair share in the company's profits". ${ }^{19}$

After the war, the new Fordist economic regime was seen as an acceptable solution by the people who before the war had been seeking a third way. The old problematics had also taken on new relevance because of the power of the communist movement, which had emerged strengthened from the war years, and the violence of contemporary political and union contestation, which some feared would result in communist rule. It was urgent to provide guarantees of the intention to share the benefits of future growth, and to find a new equilibrium for employer-employee relations within the organisation.

In accordance with this preoccupation, the writings on budgetary control were careful to explain how budgetary control is capable of resolving the class conflict, and often professed their belief in the Fordist solution, which dominated most

\footnotetext{
${ }^{19}$ Penglaou (1935) can also be quoted for the 1930s. "In this new technique, the forecast, based on highly detailed programmes and budgets, gives rise to a sort of work charter, which will be the firm's law for the period concerned... Budgetary control becomes a management method that entails interdependence of all the firm's component bodies, bringing about coordination, and harmony between resources."
} 
discourses at the time. We can quote again the report issued by the 1951 OECCA mission: "It appears that the USA is seeing the blossoming of a new manager class (...) which, fully conscious of its responsibilities and prerogatives, does its best to integrate and harmonise its efforts with those of the working class, with the general goal of greater productivity and promoting well-being".

Jean Milhaud, in a lecture on budgetary control in 1952 (CEGOS, 1953), explained we are in: " $a$ time when constructive efforts are being made at all levels of the company to underline the eminent place of man in production and make him an enlightened partner in management's action (...) We also know that only those enterprises with a budget system that branches out to its extreme can calculate the immediate repercussions of simplifications proposed at the level of a particular department or workstation, and thus distribute some of the expected savings to the originators of the suggestions, according to their policy. In such a case, financial and human management techniques are interdependent."

Thus, the writings in our corpuses point up the economic and social problems which were under debate during the period. We now show that our authors did not simply consider budgetary control as a potential solution to the problems discussed. On a deeper level, the evidence suggests some of them supported the models of society recommended by the various reforming currents. This calls for a more detailed examination of those currents.

\section{Reforming currents}

Three main configurations of reforming ideas have been identified from the work of the historians and sociologists. These ideas seek to supply responses to the various challenges described above. All three are intricately interrelated, borrowing themes from each other while remaining individually distinct. As Boltanski (1982) and Kuisel (1981) point out, these three currents are more in continuum than in opposition. The ideas are in fact closely related, but expressed differently. The first (corporatism) disappeared with the war, but the second (planisme, then technocracy) adapted and successfully lasted beyond 1945 . The third, which is difficult to classify - we shall call it "economic humanism" - sprang up in reaction to war, and also doubtless in response to American influence. Often dominated by a minority elite, these new philosophies sought new foundations for economic growth, and grew in importance with the rise of new social groups such as the middle classes. This was a genuine "work of ideological redefinition", mainly concerning the bourgeoisie who were looking for a "third way".

\section{Corporatism}

Corporatist doctrine places the collective interest at the centre of society; it is thus in direct opposition to free market capitalism. Already deeply rooted in European culture (Cotta, 1984), this movement must be seen in the light of the rise of fascism, which took place at the same period in Germany and Italy. Corporatism's big idea was the recreation of corporations, similar to the former guilds (métiers), professional bodies made up of individual practitioners of the same craft, regardless of class, i.e. workers and employers together. "These bodies would assume the task of arbitrating industrial disputes, fixing work conditions, controlling prices, and determining the quality and even the quantity of the output. And in a corporatist state a system of professional representation elected an economic assembly that bypassed party politics and strenghtened the republic's competence in economic affairs" (Kuisel, 1981, p. 103). Nevertheless, for corporatists, the state was not supposed to direct the economy, as only corporatist organisations were considered competent to do so.

Corporatism, which stems from Catholic social doctrine and the Christian critique of materialism and individualism, can be seen as a reaction to other concepts of society that were put forward at that period, namely the free market economy, accused of generating chaos, selfishness and materialistic attitudes, and Marxism, criticised for stirring up class hatred and destroying social solidarity. Trades unionism was not considered any more acceptable, since it expressed the same class struggle. Corporatism advocated replacing the working class revolution by a spiritual revolution in which the different social classes, once organised, should work together. Turning its back on the impersonal nature of largescale capital, the corporatist society would be based on the small businessman and his patriarchal virtues: personal responsibility would be directly invested into the job to be done, the capital and the jobs would be in the same hand, and employment relations would be magically transformed by paternalism (Boltanski, 1982). The aim was thus to restore social order and harmony within business organisations. "They were social conservatives who 
wanted to revive such cherished values as hierarchy, family, discipline, class conciliation, religion and work" (Kuisel, 1981, p. 102).

One of corporatism's most noticeable impacts during the 1930s lay in the support it provided to restrictive practices and cartels between producers. Rather than being governed by market forces, the economy could be managed collectively in an optimal manner. Cartels were not a new phenomenon under corporatism, but corporatism provided them with justification. This ideological current reached its zenith under the Vichy regime, which "officialised as State ideology, and in its institutions gave concrete form to, most of the themes dear to the catholic engineers of the nineteen thirties" (Boltanski, 1982, pp. 132). After the war, some of these ideas persisted, but with profound transformations.

References to the corporatist ideas turn up regularly in the texts examined, for example in Musil (1930): "The use of its methods [i.e. the methods of budgetary control] and the acceptance of its principles engender the right mental attitude for better cooperation and better coordination of individual efforts." Similarly, Bourquin (1937) believed that budgetary control could help structure the French industrial scene in a purely corporatist logic: "These standard prices (...) can be compared with information supplied by competitors, thus providing a solid basis for negotiation when an agreement is introduced between producers. Practical experience shows that the first measure to be taken is to develop standard prices, which will be useful for all members of a corporation, enabling them to see the situation as it is and talk the same language". Pulvermann (1930), after a long discussion of the difficulty of establishing forecasts, related this effort to cartelisation: "In this matter, it is down to science to supply at least a few fundamental rules, and it falls to the unionsand the cartels, working together on an international level, to consolidate the situation by practical means".

The IIOST congress of 1930 shows that for the reformers (represented here by Serruys, a member of the Economic Committee of the Society of Nations (SDN)), the link between the corporatist approach and the budget is clear; he explains that "there are collective methods which should be followed, there are efforts to be made by the unions and professional bodies. Budgetary control must leave the purely individual domain of one factory's experience and become the concern of a whole profession, or a whole sector of industry." (Serruys, 1930). At the same congress, meanwhile, Satet proposed set- ting up "national groups for budgetary control", saying that the CNOF could take charge of this for France. The different countries' national committees would then be federated into "international budgetary control groups organised by industry".

\section{Planisme and technocracy}

While corporatism sought to overcome" the anarchy of individualism" by, as Kuisel (1981, p. 102) puts it, "reconstituting the natural cells of social organism", the planners were looking for a way "to manage the economy". They wanted to preserve the free market system by adapting it and reducing the social tensions it generated. They believed that system needed structural reform to combat the violent economic disorder created by market capitalism. The main tool of this new order was economic planning. Kuisel (1981) distinguishes two major trends in planisme: neo-liberalist planners and syndicalistsocialist planners. ${ }^{20}$ These trends form the basis for the interventionism that took place after 1945.

Technocracy is another expression of planisme; the term only appeared after 1945 . It refers to a certain concept of decision-making (Kuisel, 1981), according to which there is only one right solution, that can be found by experts. This is shown primarily in the desire expressed by certain intellectuals to introduce a "planned" sector, which would contribute to efficient regulation of the economy. Management of this sector would be entrusted to a "body of men governing the pace of the economy without having any personal interest in any of the enterprises, but guided only by team spirit as regards the people under them" (Coutrot, 1936). For its advocates, this planning would make it possible to establish "fair prices", make accurately efficient use of production resources and achieve "the distribution of prosperity" (Coutrot, 1936).

The development of technocracy and planisme in the 1930s continued after the war with French-style planning and the Keynes-inspired policies that were in operation at the time. But in contrast to the "back to the land" policies of the Vichy regime,

\footnotetext{
20 "While the first embraced planning to perfect capitalism, the second did so to build socialism" (p. 105). These two currents had several points in common: reason, controls, and planning were to replace the natural mechanisms of the market. Neo-liberal planisme attracted managers, engineers and high-ranking civil servants, people who valued forecasting, controls, self-discipline and cooperative networks. Socialist trades unionist planners, on the other hand, were in favour of nationalisations, rigorous interventionism and trades unions.
} 
the postwar reformers chose a "forced march" industrialisation approach to first rebuild the country, then catch up with other industrial nations. The ideas were quite similar to pre-war thinking, except that technocracy was now totally converted to Keynesianism, ${ }^{21}$ and there was massive importation of American concepts of management.

The planners' ideas, meanwhile, are visible, to take one example, in Coes (1930): "in adopting the budget procedure, we are thus recognising the importance of looking far ahead, and showing that we believe in the possibility of forecasting, and the practical usefulness of forging ahead in the light of what has been planned". Serruys (1930), as already seen for corporatism, appears to have combined it with planisme: "In short, a budget clashes with the initiative of the organized collective operations. (...) And this is how a budget that is controlled, studied together (...) cannot only be a part of beneficial, concerted private initiatives, but must also contribute to rectification, one could almost say guidance, of the nations' economic policies". In the opening pages of his book, Ludwig (1930) writes "the introduction of the budget in an industrial operation (...) requires the innovation of a new economic guiding principle, a principle that assimilates the advances of economic science, and is opposed to the laxity of old commercial tradition". Reitell and Lugrin (1936) also explain that thanks to budgetary control we move "from anarchic freedom to a freedom directed, supported and controlled by bodies with the necessary capacities and technical equipment".

In fact, regarding firms' internal organisation the planners' ideas are so close to those held by the promoters of budgetary control that it is hard not to see this as a result of the double enrolment we seek to describe. The central importance attributed to the governmental technologies of budget and budgetary control by the planners, and the hopes of regulating capitalism held by promoters of budgetary control, appear to be superimposable discourses. Development of budgetary control benefited to the full from the passion for planning that affected all French reformers of the time, whether neo-liberal, corporatist or socialist. All appeared to agree on at least this

\footnotetext{
${ }^{21} 1945$ saw the establishment of the ENA, Ecole Nationale d'Administration, designed to replace the Ecole Libre des Sciences Politiques as supplier of high-ranking civil servants. Meanwhile in economic teaching, Keynesian ideas were taking over from the doctrinary free market ethic (Kuisel, 1981, p. 215).
}

point. Implementation of State planning under the Vichy government, then, in a different way, by the Keynesian postwar state, can be seen as part of this major trend. It is difficult not to see this craze as an effect of competition from 'real socialism' countries, whose planning projects are adopted to abolish capitalism, not to control it. ${ }^{22}$

\section{Economic humanism}

The most obvious American contributions to French business concern the methods for social control and settlement of conflict within the enterprise. This is reflected in the importation of human resource technologies inspired by the Human Relations movement, which recommended increased decentralisation of decision-making within the organisation as a means of increasing managers' responsibility and motivation. Perhaps a better term would be "economic humanism", a phrase coined by Coutrot (1936), as the ideas developed after the war were not totally new, and it is not always easy to distinguish between theories brought in from America and those taken up from the 1930s. The standard example of economic humanism in action in the 1930s is the case of the shoe manufacturer Bata, often analysed and referred to in reforming circles before the war, but without attracting great interest in the business world. It was introduced by Hyacinthe Dubreuil ${ }^{23}$ in a book published in 1936, and was

\footnotetext{
${ }^{22}$ Penglaou (1931), for instance, thought it necessary to explain that budgets are not the first stage towards socialisation of production resources typical of a planned economy such as the USSR. Pulvermann (1930) also discusses the theme that making forecasts was long considered a suspect activity, because it was seen as socialism.

${ }^{23}$ Hyacinthe Dubreuil is one of the period's most interesting characters. A bluecollar worker and former CGT union member, he began travelling in 1927 and was engaged as a mechanic at Ford in the US (in Detroit). This experience was the basis for his bestselling book Standards, which placed him at the centre of debates on scientific management. Dubreuil appears to have had a dual-faceted personality: on one hand, he was a popular investigator into workers' conditions, and on the other a marginal but persistent campaigner for a new organisation of workshops that could achieve "workers' liberation" (Ribeill, 2003). He argued for the creation of economically and financially "autonomous workshops", where the worker could learn about work management and receive "the means of fulfilling his existence on all three levels, economic, intellectual and moral, for otherwise hopes of achieving social peace will always be in vain". From 1930 to 1938, Dubreuil held office at the International Labor Organisation. His numerous writings left a mark on the entire period.
} 
taken up by certain other authors (e.g. Landauer, Coutrot, and others). The fact that it was taken up by promoters of budgetary control is a sign of the in-depth knowledge some of them had of contemporary reforming ideas. Thomas Bata's major contribution lies above all in his management of personnel. His "key idea was to work on the working class mentality so as to take it from an employee mentality to an entrepreneur mentality" (Landauer, 1933). He introduced a supervisor for each workshop, who worked for the company but formed an autonomous team with his workmen. The various workshops were linked by a system of internal transfer prices. The aim was to make employees as autonomous as possible, putting them "in the boss' $s$ shoes", using the method successfully developed in France by Lucien Rosengart and known as the "small businessmen method (méthode des petits patrons)". Bata's principles consisted of giving more responsibility to actors in the business. Rimailho (1936) and Satet and Voraz (1947) noted the importance of these autonomous groups in the healthy situation at Bata. This example was almost forgotten after the war even though the issues it raised became much more widespread, and formed the new management ideology.

The notion of responsibility centres, largely absent from business practices in the 1930s, developed in the 1950s as organisations' desire for greater decentralisation grew, and is one consequence of the emergence of these ideas. All the thought systems of the traditional employer class were challenged. The final objective, however, remained the same: to succeed in increasing cooperation between employers and employees. In the words of Boltanski (1982), the goal was to "achieve what corporatism had failed to do, but by other means" (p. 160).

The big new idea of the postwar period, decentralisation, is present in the texts we studied. As J. Benoit remarked (1956, author's capitals): "the most efficient management method once a business reaches a certain scale is THE METHOD WHICH SEEKS AND INVOLVES APPROVAL AND PARTICIPATION BY THE LARGEST POSSIBLE NUMBER OF ALL INTERMEDIATE LEVEL EMPLOYEES, the method in decentralised form." (p. 9). He tirelessly repeats this theme in his lectures, for example in 1958 at the Sorbonne: "We also need an organisation based on decentralisation and trust. (...) We need to organise matters so that the humblest employee still retains a certain feeling of free- dom, initiative, responsibility and dignity." (p. 6). Similarly, for Guillaume (1958), "budgetary control can also be used as a canvas for general application of the principles of human relationships and public relations" because it is based on delegations of power and authority, and can establish bottom-up and top-down communication along the hierarchy. It should not be forgotten that the Fordist creed and pro-American management propaganda were widely put forward by our corpus authors in the 1950 s, often on returning from productivity missions.

Thus the ideas and solutions proposed by the reform currents are also expressed in the texts written by the promoters of budgetary control in each of the two periods. Evidence of this is found whatever the level used for analysis of double enrolment, whether it be certain authors' direct membership of reforming circles (Section 'Promoters of budgetary control and their relationships with the reforming networks'), presentation of budgetary control as a solution to the major issues addressed by the reformers (Section 'The economic and social problems evoked by social reformers and promoters of budgetary control'), or the degree to which the budgetary control promotional discourse is embedded in discursive worlds even more strongly marked by the reforming currents (the prewar corporatist or planners' idiom or the postwar Fordist creed at macro-economic level, presented in the form of economic humanism in micro-economic practices) (Section 'Reforming Currents').

The political rationalities that budgetary control is likely to serve evolve with time, but it is also striking that as the subjects of concern to reformers and promoters of budgetary control changed over time, their conception of budgetary control also altered. We now show the malleability of the definition of a governmental technology as it is penetrated by changing political rationalities.

\section{Budgetary control: a concept that evolves in association with reforming ideas}

It is impossible to separate the socio-political from the technical. Programmatic aspects are incorporated and reified in what is subsequently presented initially as purely technical. Budgetary control is gradually transformed according to the programmes it is intended to serve, while as a technical object retaining a certain independence of the 
discourse, and also putting up some resistance to its enrolment. The work of adjusting its characteristics and uses to new political rationalities is a social work in its own right, requiring new investment in form (Thévenot, 1984) likely to bring about change in the form and fix it for a while. When this remodelling occurs, the interpenetration of the political and the technical is clear, for example from our selected texts. Next, the form may circulate while apparently devoid of any ideology. Once the black box is closed, the traces of the various enrolments that transformed it are obliterated (Latour, 1987). This phenomenon, in our opinion, explains why for management tools, most discourses remain in the technical register: cruising speed is reached for a tool that can now circulate in a form that needs no further explanation, defence or justification. People simply need to be taught how to use the tool, without needing to understand the underlying rules and to adhere to the underlying values. At least two meanings of budgetary control existed successively over the period studied.

\section{A rationalization tool}

The 1930s definition of budgetary control stressed its usefulness as a rationalisation tool. This rationalisation was coherent with both the planners and the corporatist approach. It was the cornerstone of the third way sought by reformers, and in keeping with the Taylorian schema, it was hoped it would take society beyond the class struggle. Rationalisation of industry was to be achieved by the planning effort demanded by budgetary control and coordination at national level. It was generally considered that when problems are considered in a rational way, it is possible to solve them. This desire to create rational order is found in most of the texts from the 1930s. Satet (1936), for example, supplies the following definition: "budgetary control based on an accurate examination of everything that can be expressed in figures in a firm, whatever its nature, form or importance, consists of strict analysis of past events and forecasts of probable events, in order to establish a rational plan of action." Behind this view of budgetary control, there is a very mechanical dimension: it is the tool used to rationalise management's tasks, just as time and motion studies had resulted in rationalisation of workers' tasks. Some went as far as to consider budgetary control as a way of introducing a kind of Esperanto for all com- pany members. For example, Commesnil, in the CNOF review, expressed his hope for the emergence of a new common language and standard values. Classification of accounts on the same basis within the company, he argued, should make it possible to make compare its various departments. The internal coordination made possible by budgetary control could be extended to coordination external to the company.

\section{A motivation tool}

After the Second World War, budgetary control began to play a broader role. No longer confined to a merely technical dimension, it also took on a "human resources" dimension. It was now a management tool that would foster personal fulfilment in the workplace by granting greater freedom to the individual. However, its original dimensions remained: budgetary control was still seen as a tool for forward planning, coordination and optimisation. Now, though, it was seen more frequently than before as a means of motivation for managers. The major source of this motivation was the decentralisation of authority structures, which developed in parallel with budgetary control. The as yet unknown idea of raising motivation through fixing objectives, and the debates about the right level of objective-fixing needed to motivate senior employees were only to be added to this picture in the 1960s.

Definitions of budgetary control also became fuller. In 1951, the report produced by the accountants' productivity mission stated that budgetary control was " a set of coordinated forecasts for a limited period of time, generally the year, established so as to allow early identification of operating conditions and Profit and Loss account items, dividing these forecasts up in such a way that it is possible to appoint a person responsible for each one, systematic reconciliation at fixed periods, generally monthly, of the actual results in the various management areas with the forecast results, speedy communication of the related information not only to Management, but to the persons responsible, down to fairly low levels in the hierarchy" (OECCA, 1951). In the list of the "aims" of budgetary control given by the authors of the same report, the foreground was no longer occupied by the issue of rationalizing the economy. The following aims were listed "in order of importance": "(1) For Management, it is a convenient way of decentralising responsibility without forfeiting 
control; (2) It is the simplest way of practising management by exception at all levels of the hierarchy and for all management factors; (3) It is a means of showing everyone the road Management intends to follow in directing the company. (...) It is the means of indicating in detail to each co-worker what is expected of him, and thus making the necessity of personal effort an accessible notion; (4) It is a very reliable way of detecting certain errors in organisation, particularly duality of responsibilities." (p. 36)

We have just seen that the history of budgetary control is closely related to the incorporation into economic practices of ideas that originally germinated in reforming circles. The number of such circles was on the increase in the 1930s in response to what was analysed as a deep-seated crisis of capitalism. The renewal of budgetary control was possible after the war through in-depth reforms and a shift in state policies. In business, a new style of management developed, which altogether gave rise to what Boltanski and Chiapello (2005) identify as the second spirit of capitalism. Their work is devoted to the transition from the second to the third spirit of capitalism, and the picture it paints of this second spirit based on a corpus of management texts dating from the 1960s corresponds to a fairly late period, with Management By Objectives appearing as the central device, while it had not yet been mentioned in the 1950s texts studied for this article. And yet it is well known that MBO were added to budgetary control practices. Budgetary control is not an innocuous tool in the history of 20th century capitalism. It occupies the position of one of the central management tools that can be used to perform the second spirit of capitalism. This partly explains why it developed in parallel to the growing success of reforming ideas of the 1930s. The materials collected for this article also provide an exceptional opportunity to further understanding of the gradual transition from the first to the second spirit of capitalism.

\section{Gradual transformation of the spirit of capitalism as seen through the budgetary control tool}

The spirit of capitalism of a period, Boltanski and Chiapello (2005) have suggested, should always promise three things: security, stimulation and fairness. Below, through the texts of our corpus, we examine how these three promises were affected over the period studied, generating a significant change in the spirit of capitalism.

\section{The promise of security}

In the 'first' ${ }^{24}$ spirit of capitalism, security was to be guaranteed by the very form of the economic fabric, woven from small family run businesses building on local networks and trust of the kind found in family relationships. Security was to be achieved through protection of personal relationships within the family in its broadest sense (if the employeeemployer relationship is taken into account). In bigger enterprises, active paternalism by the company director was to provide the workers with a form of protection.

But this form of security, specific to the "first" spirit of capitalism, was shattered in the inter-war period, which saw the development of financial capitalism and large companies that turned their backs on the family business capitalism, and also the economic crisis of the 1930s, resulting in a significant fall in paternalistic protection. The reformers did not all have the same solutions to recommend in this situation. Corporatism was more interested in the old form of the promise of security, and its proposals were along the lines of abolition of international, impersonal financial capitalism in order to go back to capitalism founded on small-businesses and personal relationships. In contrast, the planners and Taylorian economists thought it was possible to build a new form of security through rational organisation of labour and planning. In general, discussions of budgetary control, even when the authors were totally in agreement with the corporatist idea of coordination by profession, tended to give priority to the new form of security.

The speakers at the 1930 conference frequently underlined the promise of security conveyed by bud-

\footnotetext{
${ }^{24}$ This article talks of the "first", "second", and "third" spirits of capitalism with reference to Table 1, which only concerns late capitalism. Under no circumstances is it suggested that the first spirit referred to in this way is the spirit of the original capitalism, the only one of interest to M. Weber. Although Boltanski and Chiapello (2005) follow Weberian tradition in placing the ideologies underlying capitalism at the heart of their analyses, their use of the concept of the spirit of capitalism departs slightly from the standard approach. For Weber, the concept of spirit is part of an analysis of the "types of practical rational behaviours", and "practical incentives to action", which because they make up a new ethos, have made it possible to break with traditional practices, develop calculative mentalities, remove moral condemnation of profit and start the process of unlimited accumulation. Boltanski and Chiapello (2005) do not aim to explain how capitalism came about, but to understand how in various periods it has succeeded in attracting the actors needed to generate profit.
} 
getary control. One example is Jadot (1931), who noted: "I think that if budgetary control had been used everywhere in worldwide industry, we would not have seen the irrational excesses of production observed in most industries, and consequently the current crisis would not have been so catastrophically intense as it is". Coes (1930), meanwhile, explained that "from one essential standpoint, the main aim of budgetary control is to provide a means of control, to restrain and stabilise fluctuations in business volumes, which would otherwise be irregular." Serruys also remarked (1930): "Once we have shown public opinion (...) that it is necessary to make forecasts, and adjust the activity to those forecasts, perhaps we will prevent these wide fluctuations."

These hopes in the construction of a new form of security through planning took concrete form in the postwar period. The Keynesian state adopted the philosophy of planning, and the advocates of budgetary control were thus recommending a tool that was perfectly suited to the ideas of the public reformers. The spectre of the mass unemployment experienced in the 1930s was still haunting all efforts to construct a new form of security in the 1950s. For example, Loeb (in CEGOS, 1953) discussed his desire to avoid unemployment for as many as possible. Budgetary control would provide a solution, since better rationalisation of production resources would mean that the labour force could be used in a more regular manner: "and in this way, we will be able to eliminate, or at least reduce the number of, those notices posted outside the employment offices advertising for workers to enter the labour market, and which most unfortunately bring to mind their counterparts, the notices in shops showing the items they want to sell off on their buyer's market. It will be a long-term effort, and the company must be able to pursue this strategy using its own resources, without ignoring the efforts made by the government."

For the National Productivity Committee (Comité National de la Productivité), budgetary control was more than just a technical end for companies. It was a political, micro-economic arm in the struggle against the inactivity forced on employees (unemployment) that was generated by a lack of rationalisation. Their pamphlet "The Budget, Your Best Tool" (1952) stressed the regular production levels attained thanks to budgets and forecasting. The idea is to replace adjustments, which take place to the detriment of employees, by greater rationality. Coordination and regular flows should make it possible to avoid occasional periods of unemployment, and also costly overtime. If the worker can work in peace and confidence, in the knowledge that full employment is guaranteed, then he participates more actively and contributes to improved productivity.

Jean Parenteau (with the help of the CEGOS, of which he was a member) published one of the most important postwar books on budgetary control. In his introduction to the third edition in 1959, he justified the use of new control techniques: "The collective enterprise represents, more than a pool of capital, a set of social interests: for a certain number of people and families, living conditions are linked to those of the company, and if it fails, employment and the poverty it causes are the immediate consequences. The company manager has a duty to maintain the level of activity in his workshops, and he can only achieve this by very close supervision of his enterprise. Accounting is the most efficient way for him to exercise such supervision."

\section{The promise of stimulation}

The "first" spirit of capitalism declared its faith in technical progress, and promised fulfilment for the entrepreneur. This promise appears to have remained unchanged in the 1930s, even though, as we have seen, the spirit of capitalism had already begun a transformation in its proposals concerning security.

Taylorian engineers continued in the tradition of the Saint-Simonians, referring to previous experiments in French-style management. ${ }^{25}$ The enthusiasm of the 1930s was generated by the ever greater progress being achieved by mankind in controlling the world through reason, science and technical knowledge. From this point of view, budgetary control in the 1930s carried a promise of stimulation totally in keeping with the first spirit of capitalism. For example, Coes (1930) explained that: "When a man has accepted the idea that the adoption of a budget is not there to restrict or confine him, but that it is in fact a way of making him master of his own task instead of being dominated by that task, then we have removed one of the major points of resistance to the budget".

\footnotetext{
${ }^{25}$ See, for example, the case of Rimailho mentioned by Lemarchand (1998), or the case of Coutrot described by Dard (1999)
} 
This ambition to control the world through science, including management science, was much less marked in the years following Second World War: the horrors of Nazism and the atomic bomb had disillusioned the champions of technical knowledge and the liberation of mankind through science. The promise of stimulation thus had to be renewed and altered in the 1950s. During that period, the promised momentum was expected to come from decentralisation of responsibilities and personal fulfilment in the workplace. The seeds of this new promise of stimulation were already present in the 1930s, through the example of the Czech company Bata. Whereas it had not interested a very wide audience in the thirties, the situation was different after the Second World War. The productivity missions provided one opportunity to develop this new promise of stimulation, through importation of American human resource technology and France's discovery of Fordism. Returning from a mission to the US (OECCA, 1951), the French accountants were highly enthusiastic about American business: "There is no conflict between social welfare and the company's interest in survival. Both coexist in harmony, both obeying the same rational rule, both are measured at the same time and by the same standard." Another example can be found in J. Benoit's often-quoted speeches: for him, the accountants and controllers were to be at the heart of economic renewal, and its use to serve humanity.

\section{The promise of fairness}

A dual form of fairness underpinned the first spirit of capitalism. First, emphasis was placed on a market type of fairness (Boltanski \& Thévenot, 2006), a type of social Darwinism where the most competitive survives. This form of fairness is coherent with the free market ethic prevalent in late 19th century/early 20 th century France. The market was believed to be self-regulating, and underperformers were eliminated. This form of fairness cohabited with a highly contrasting "domestic" fairness (Boltanski \& Thévenot, 2006), which emphasised fidelity to tradition and respect of the father figure. People were treated according to their position in the domestic hierarchy and their respect of bourgeois precedence. The dutiful son inherited his father's place because he was the heir, not because he was competent, as an "industrial" fairness might require, nor because he was the most competitive, which would be in keeping with market type fairness.

This curious alliance contained in the promise of fairness of the first spirit of capitalism was greatly affected by the growing criticism of the free market economy in the 1930s, a great motivation for seekers of the "third way". Domestic fairness, meanwhile, was never really challenged - although that was to change significantly in the 1950 s.

Over the whole period, a new promise of "industrial" fairness - characteristic of the second spirit of capitalism - was gathering force. This was built on a hierarchy of competence, selection and promotion of the best performers, an ideal social order capable of legitimising the new social group formed by professionals and managers (cadres), which by definition, could not claim legitimacy by ownership as grounds for its authority.

The seeds of this new promise were visible in certain texts of the 1930s. Musil (1930), for instance, in an article titled "Cooperation, manager training, wellbeing of the Nation", declared that: "Budgetary control methods have a point of excellence: they provide criteria that can be used to assess merit, and therefore enable the manager to appreciate to what extent the individual assumes his responsibilities successfully and continuously." Landauer (1930) was also sensitive to the new form of fairness which should result from budgetary control: "Based on scientifically established standards, it [the budget] makes it possible to reward everyone's efforts according to merit, and provides a fair, practical solution to the highly controversial problem of fair distribution of corporate profit."

The period following the second world war extended this promise (the great advantage of budgetary control was, according to J. Benoit, that it "replaced human judgment, which is always awkward and delicate, with judgement by figures"), but added to it the affirmation of a more important place for Man in the production process, and a promise of fairer distribution of the fruits of growth, which budgetary control was believed to facilitate.

Analysing the shift from the first spirit of capitalism to the second, based on the texts on budgetary control, we see that the transformation did not happen at the same pace for the three promises of security, fairness and stimulation. The first spirit appears to have reached a crisis when its promise of security turned out to be incapable of standing up the depression of the 1930s, and market type fairness was challenged by the failures of the free market system 
revealed by the same crisis. The solutions for each of these dimensions placed priority on rationalisation systems, whether in the form of Taylorism or planning. These new systems were seen in the 1930s as capable of calming the newly emerging anxieties concerning security and fairness, while being a natural extension/continuation of the first spirit in their enthusiasm for scientific knowledge and confidence in technical progress. Security by forward planning, and fairness by calculation were contemplated, but these proposals were only effectively implemented after the war. It was also only after the war that the promise of stimulation was reconstructed around the central concept of personal fulfilment in the workplace through decentralisation of responsibilities, and the break from the first spirit of capitalism was thus finalised. The transformations in the concept of budgetary control during the 1960s, not covered in this article, continue the definition of this stimulation dimension with the MBO system and the quality of the new meritocracy.

Boltanski and Chiapello (2005) suggest that the shift from the second spirit of capitalism to the third also took place at differing paces for the various promises. However, this time, the stimulation promises has been the most significant, the first to enter the crisis and the first to remould its proposals, while the new promises of fairness and security are taking their time to settle into practical form.

\section{Conclusion}

This article has tested a certain number of hypotheses on the relationships between the dissemination of a management technique and the reforming ideologies of a period, in continuation of the work by Miller and O'Leary (1987, 1989, 1994), Miller and Rose (1990), Miller (1990), Rose and Miller (1992) who discuss the relationships between political rationalities and governmental technologies. These relationships are placed here in a dialectic schema of transformation of the ideologies that accompany capitalism (Boltanski \& Chiapello, 2005), which attributes an important role to the critical discourses on capitalism and the work of social reformers to change it. The framework for change in society is based on the sequence: (1) crisis, (2) criticism of capitalism-reform proposals, (3) incorporation of those proposals and transformation of capitalism. In the case under examination, budgetary control was promoted as a solution, which - generalised to all companies and associated with suitable national economic policies - would be able to discipline capitalism and bring about both security for workers and a merit-based form of fairness in the workplace. This formula, which lies at the core of justifications specific to the second spirit of capitalism (Boltanski \& Chiapello, 2005) gained resonance in people's minds as the models of society recommended by 1930 s reforming think-tanks were increasingly accepted, and practices evolved accordingly (intensive training in management technologies imported from the US after 1945, dissemination of budgetary control practices, reform of structures at State level, etc).

This consubstantiality of budgetary control and the mentality typical of the second spirit of capitalism also explains why it was so easy to observe the double enrolment process: the tool was adopted by reforming currents as a solution to the problems of their time, and the reforming discourses were used for its promotion.

We were able to describe this enrolment at different levels: first, we saw that certain major think tanks had taken the lead in publications on budgetary control, and that the principal promoters of budgetary control were themselves members of these reforming groups. We also showed that not only did the writings promoting this management technique tend to present budgetary control as a solution to the economic, social and moral troubles under debate in reforming circles, but often there was a rhetorical background consisting of the models of society or organisations recommended by the main reforming currents (at least, by those that historians have taught us to consider as pioneering arenas in the search out for a third way between economic liberalism and State socialism, and where the policies implemented first by Vichy, then by the Keynesian postwar state, were devised).

As the material we have worked on for this study consists mainly of public discourses, we have been unable to demonstrate directly the influence of these discourses on the practices and mentality of anonymous practitioners; at best, we can hypothesize. The first change in practice is the increasingly widespread adoption of budgetary control by firms over the period, which we know from other work was a real observed phenomenon. This spread took place in a context of high mobilisation for reforming projects, although we have no way of knowing whether the technique would in fact have spread without this 
mobilisation, by dint of its own efficiency or other factors, such as power struggles. Nevertheless, the theoretical analysis frameworks we use tend to take discursive activity seriously, and consider that it plays at least a cognitive role (influencing actors' modes of interpretation) and a political role (legitimising certain forms of order to the detriment of others). For this reason we can also hypothesize that the practice of budgetary control itself changed with the shift in its definition from a rationalization tool to a motivation tool. Longitudinal case studies on budgetary control practices and devices and their evolution in various firms could provide information on the way political discourses are translated (or not translated) into the particular human/nonhuman arrangements studied (Latour, 1987). We hypothesize that beyond the singularity of the situations studied, it would be possible to find similarities between the arrangements of a given period as long as the situations studied belong to the same institutional configuration, i.e. are fairly closely linked by devices and networks that produce and reproduce it and which are inextricably technical, political, cognitive and moral.

This study asks the question of the uneven importance of various tools, according to the institutional features of capitalism at a given time and in a given place. Some tools, such as budgetary control, appear to "sign" the mentality of a period better than others. This remark is akin to the work of Bryer (2000a, 2000b) highlighting the existence of an accounting signature that evolves with certain states of the economic system, and also the work by Lordon (2000) on the eminent role currently played by "shareholder value" and its various measurement instruments in today's regulation of capitalism. According to our own analysis framework, certain management instruments are more important than others, because they equip the trials a society deems central at a given moment (Boltanski \& Chiapello, 2005; Bourguignon \& Chiapello, 2005). The way they organise these trials is a sign of the preoccupations that engendered the tool, and of specific points of interest in the criticism, which tends to focus on certain problems that vary with the period, as well as a set of particular values and representations - in other words, a mentality. It can be hypothesised that the more central a management tool is, the more its establishment has involved intense discursive activity and an enrolment of socio-political rhetoric going beyond arguments of economic effectiveness alone, and the more it has taken place under the influence of a systemic transformation of the economic system.

These considerations also make it possible to understand the close interdependence between the concept of a practice (or the definition of a management tool) and the most predominant social and economic political rationalities of a period. In the case of budgetary control, we have seen how it was loaded with changing programmatic aspirations, gradually becoming a tool for increasing responsibility and motivation, having started as a project marked by a desire to rationalise.

Various frameworks now exist to analyse the varying forms of capitalisms existing in different countries at a given time, or at different times in the same country (see for example Boyer, 2002; Crouch \& Streeck, 1996; Hall \& Soskice, 2001). On the whole, however, these analyses tend to ignore both the world of ideas (although they study and compare the institutions, they tend to neglect ideologies as social institutions) and the role of governmental technologies. Some accounting research is itself inspired by these frameworks, e.g. Puxty, Willmott, Cooper, and Lowe (1987), but not much has examined the institutional role of accounting devices in specific economic configurations. This article has attempted to show that it is possible to extend analyses of different types of capitalism into analyses concerning the movement of political ideas, and that accounting practices could also find a place in such a research programme.

\section{Acknowledgements}

Previous versions of this article have been presented at the seventh Interdisciplinary Perspectives on Accounting Conference in Madrid (2003), the research seminar of the sociology department of the Università degli studi di Milano-Bicocca (2003), the research seminar of the doctoral School in Management of the University of Paris XII-Créteil (2005) and a seminar organized at the Institut für Sozialforshung in Frankfurt (2006) where we attracted a certain amount of pertinent criticism from attendees. We have had opportunity to discuss all or parts of this article with Thomas N. Tyson (our discussant in Madrid 2003), Trevor Boyns, Yannick Lemarchand, Gérard Koenig and Patrick Fridenson. The comments of two anonymous reviewers were also very valuable and made us improve a lot 
the paper. Our thanks are extended to all. We are also indebted to Ann Gallon for her much appreciated editorial help.

\section{Appendix: Corpuses of reference texts}

A brief description of the corpus referred to is given below, but for reasons of space bibliographical references are only provided for the texts cited in the article.

\section{$1930 s$}

The starting point for budgetary control in France and Europe is certainly the international conference held in Geneva from July 10th-12th 1930 on the theme of budgetary control organised by the IIOST. There are two sources for consulting the speakers' presentations made to the Geneva conference:

- IIOST (1930), Conférence internationale du contrôle budgétaire, Genève, rapports de la conférence, 2 volumes available for consultation at the French Bibliothèque Nationale.

- Special issues summarising the conference was also published in the business journal Mon Bureau in August and September 1930, quoting the following:

Coes (1930), Difficultés et résistances fréquemment rencontrées dans l'instauration de la procédure budgétaire, Mon bureau, Septembre, pp. 389-392.

Jadot (1931), Le contrôle et la gestion des entreprises à l'aide du budget, Mon bureau, May, pp. 291-293.

Landauer E. (1930), Les bases d'un budget des dépenses, Mon bureau, August, pp. 349-350.

Musil M.F. (1930), Principes et méthodes du contrôle budgétaire - Ses aspects généraux, Mon Bureau, Septembre, pp. 398-399.

Pulvermann H. (1930), Les organismes centraux de l'administration industrielle et le contrôle budgétaire, Mon Bureau, Septembre, pp. 400-401.

Schmidt M. (1930), Le budget d'investissement, les affectations de capital et le système budgétaire, Mon bureau, August, pp. 351-352. Serruys D. (1930), Le système budgétaire et l'organisation économique nationale et internationale, Mon Bureau, September, pp. 395397.
Other sources for the 1930s

Ludwig H. (1930), Le contrôle budgétaire dans les entreprises industrielles, Librairie française de documentation G. Claisse, Paris.

Satet R. (1930), La Conférence Internationale du contrôle budgétaire, IUMM, Genève.

Penglaou C. (1931), "Le budget considéré comme base de la détermination et du contrôle des crédits accordés par les banques", Mon Bureau, Octobre et novembre, p. 621 and 716 .

Saint-Pulgent (de) T. (1934), "Le contrôle budgétaire aux grands magasins du Printemps", Cégos, Document OA7, 8 p.

Penglaou C. (1935), "Le contrôle budgétaire Son introduction dans les entreprises", L'Organisation, Feb, 65-68.

Satet R. (1936), Le contrôle budgétaire, Dunod, Paris.

Reitell C. et Lugrin J.P. (1936), "Le contrôle des frais d'exploitation par la méthode des taux standards et du budget variable", Bulletin du Comité National Belge de l'Organisation Scientifique, Oct, 265-275.

Bourquin M. (1937), Méthodes modernes de répartition et de contrôle des frais généraux dans l'industrie, Dunod, Paris.

Mareuse M. (1938), Le contrôle de gestion dans les entreprises, Dunod, Paris.

About the case of the Czech shoe manufacturer Bat'a (or Bata), we quoted:

Coutrot J. (1936), L'humanisme économique - Les leçons de juin 1936, Editions du centre polytechnicien d'études économiques, Paris.

Dubreuil H. (1936), L'exemple de Bat'a. La libération des initiatives individuelles dans une entreprise géante. Paris, B. Grasset

Landauer E. (1933), L'oeuvre de Thomas Bat'a, Bulletin du CNOF, june, 177-185.

Rimailho E. (1936), L'organisation à la française, Paris.

$1950 s$

We quote the following report produced by the productivity missions:

OECCA (1951), La comptabilité au service de la productivité aux Etats-Unis - Rapport préliminaire de la mission française des experts comptables, AFAP-OECCA, Paris.

Among all the works of Jean Benoit, we quote: 
Benoit J. (1954), Contrôle à l'usage de la direction, Xe International congress on scientific management (Congrès international de l'organisation scientifique), Bulletin du CNOF, May, 22-25.

Benoit J. (1956), La prévision de le contrôle budgétaire, Workshop, January 20th-21th, Rennes, 29 p. (in Pechiney archives 001-7-30994). Benoit J. (1958), La gestion des entreprises et son évolution, A lecture given at La Sorbonne University, (in Pechiney archives 001-7-30994).

Many others conferences are stored in the Pechiney archives 001-7-30994., the "Jean Benoit Lectures", for instance:

1951. La productivité, expérience dans l'industrie, A lecture given at the Institut des Hautes Etudes de Défense Nationale.

1952. Le contrôle budgétaire français en 6 expériences. CEGOS workshop of May 5th-7th 1952. Benoit gave three talks, on "Budgetary control in the United States", "The management indicators used by general managers in the US" and "The role of the management controller" 1953. Internal memo from Pechiney.

1955. A general manager's tableau de bord, Speech given by Raoul Vitry, CEO of Pechiney, but written by Jean Benoit.

1958. Reflection on the organisation, A lecture given to the Naval Warfare College (Ecole de guerre navale). This lecture was given several years in succession until Benoit's death in 1962.

1960. A large firm's experience in organisation and methods. Army organisation committee (Comité d'organisation de l'armée de terre).

1961. Lecture to the Regional productivity committee, Lyon.

\section{Other sources for the 1950s}

Comité National de la Productivité (1952), Votre meilleur outil, le budget - Le budget par la comptabilité pour la productivité, Société auxilliaire pour la diffusion des éditions de productivité, Paris.

Charmont C. (1952), Un homme nouveau dans l'entreprise, le contrôleur de gestion, Hommes et Techniques, May, 23-26.

CEGOS (1953), Le contrôle budgétaire, 6 expériences françaises. Paris,Hommes et Techniques.

Loeb P. (1956), Le budget de l'entreprise, Paris, PUF.

Guillaume M. (1958), La gestion budgétaire des entreprises, Anvers, Editions Nauwelaerts.
Parenteau J. (1959), Contrôle de gestion par méthode budgétaire, Paris,Hommes et Techniques.

Quotations from historical material for periods not included in the 2 corpuses.

Satet R. (1942), Le contrôle budgétaire - Cours de l'Ecole d'Organisation Scientifique du Travail, Ecole d'Organisation Scientifique du Travail, Paris.

Parenteau, J. (1945), Calcul des prix de revient et comptabilité industrielle, Paris: Cegos.

Parenteau J. (1949), La comptabilité, le contrôle budgétaire et les prix standards, Hommes et Techniques, 53 Mai, 27-29.

Collective (1965), EOST, l'Ecole d'Organisation Scientifique du Travail, Bulletin du CNOF, special issue, CNOF, Août-septembre.

\section{References}

Abrahamson, E. (1996). Management fashion. Academy of Management Review, 21(1), 254-285.

Abrahamson, E. (1997). The emergence and prevalence of employee management rhetorics: the effects of long waves, labor Unions and turnovers, 1875 to 1992. Academy of Management Journal, 40(3), 491-533.

Aglietta, M. (1976). Régulation et crise du capitalisme: l'expérience des Etats-Unis. Paris: Calman-Levy.

Amoyal (1974). Les origines socialistes et syndicalistes de la planification en France. Le Mouvement Social, Avril-Juin, 87, 137-169.

Argyris, C. (1952). The impact of budget on people. Prepared for Controllership Foundation Inc. Ithaca, NY: The school of business and public administration, Cornell University.

Ashton, D., Hopper, T., \& Scapens, R. W. (1995). Issues in management accounting (2nd ed.). London: Financial Times Prentice-Hall.

Barley, S. R., \& Tolbert, P. S. (1997). Institutionalization and structuration: Studying the links between actions and institutions. Organization Studies, 18(1), 93-117.

Barley, S., \& Kunda, G. (1992). Design and devotion: Surges of rational and normative ideologies of control in management discourse. Administrative Science Quarterly, 369-399.

Baxter, J., \& Chua, W. F. (2003). Alternative management accounting research - Whence and whither. Accounting, Organizations and Society, 28, 97-126.

Berland, N. (1998). The availability of information and the accumulation of experience as motors for the diffusion of budgetary control: The French experience from the 1920's to the 1960's. Accounting, Business and Financial History, 8(3), 303-329.

Berland, N. (1999a). L'histoire du contrôle budgétaire en France. Les fonctions du contrôle budgétaire, influences de l'idéologie, de l'environnement et du management stratégique. Ph.D dissertation thesis, Paris Dauphine University.

Berland, N. (1999b). A quoi sert le contrôle budgétaire? Les rôles du budget. Finance, Contrôle, Stratégie, 2(3), 5-24. 
Berland, N., \& Boyns, T. (2002). The development of budgetary control in France and Britain from the 1920s to the 1960s: A comparison. European Accounting Review, 11(2), 229-258.

Bjørnenak, T. (1997). Diffusion and accounting: The case of ABC in Norway. Management Accounting Research, 8(1), 3-17.

Boltanski, L., \& Chiapello, E. (2005). The new spirit of capitalism. London: Verso (Translation of Le nouvel esprit du capitalisme, Paris: Gallimard, 1999).

Boltanski, L. (1982). Les cadres. Edition de minuit, Paris (Translated to English in 1987: The Making of a Class, Cambridge UP, 1987).

Boltanski, L., \& Thévenot, L. (2006). On justification. Economies of worth. Princeton University Press (Translation of De la justification, Paris: Gallimard, 1991).

Bourguignon, A., \& Chiapello, E. (2005). The role of criticism in the dynamics of performance evaluation systems. Critical Perspectives on Accounting, 16(6), 665-700.

Boyer, R., \& Mistral, J. (1978). Accumulation, inflation et crise. Paris, PUF.

Boyer, R. (2002). Variété du capitalisme et théorie de la régulation. L'année de la régulation, 6, 125-194.

Boyns, T. (1998). Budgets and budgetary control in British businesses to c. 1945. Accounting, Business and Financial History, 8(3), 261-301.

Braudel, F., \& Labrousse, E. (1979). Histoire économique et sociale de la France - Tome IV 1-2/1880-1950. Paris: PUF.

Bryer, R. A. (2000a). The history of accounting and the transition to capitalism in England. Part One: Theory. Accounting, Organizations and Society, 25, 131-162.

Bryer, R. A. (2000b). The history of accounting and the transition to capitalism in England. Part two: Evidence. Accounting, Organizations and Society, 25, 327-381.

Burchell Clubb, C., Hopwood, A., Hughes, J., \& Nahapiet, J. (1980). The roles of accounting in organizations and society. Accounting, Organizations and Society, 5(1), 5-27.

Burchell, S., Clubb, C., \& Hopwood, A. G. (1985). Accounting in its social context: Towards a history of value added in the United Kingdom. Accounting, Organizations and Society, 10(4), 381-413.

Burns, J., \& Scapens, R. W. (2000). Conceptualizing management accounting change: An institutional framework. Management Accounting Research, 11(1), 3-26.

Cailluet, L. (1995). Stratégies, structures d'organisation et pratiques de gestion de Pechiney des années 1880 à 1971, Ph.D in History, Lyon II University.

Callon, M., \& Law, J. (1982). On interests and their transformation: Enrolment and counter-enrolment. Social Studies of Science, 12(4), 615-625.

Callon, M. (1986). Some elements of a sociology of translation: Domestication of the scallops and the fishermen of St. Brieuc Bay. In Law, J. (Ed.), Power, action and belief: $A$ new sociology of knowledge? (pp. 196-223).

Carré, J. J., Dubois, P., \& Malinvaud, E. (1972). La croissance française. paris: Editions du Seuil.

Chandler, A. Jr., (1962). Strategy and structure: Chapters in the history of the American industrial enterprise. The MIT Press.

Chandler, A. Jr., (1977). The visible hand: The managerial revolution in American business. Belknap Press.

Chandler, A., Jr., \& Deams, H. (1979). Administrative ccodination, allocation, and monitoring: A comparative analysis of the emergence of accounting and organization in the USA and Europe. Accounting, Organizations and Society, 22(2), 189-205.

Chiapello, E. (1998). Artistes versus Managers. Paris, Métailié.

Chua, W. F. (1995). Experts, networks and inscriptions in the fabrication of accounting images: A story of the representation of three public hospitals. Accounting, Organizations and Society, 20, 111-145.

Cossu, C. (1986). Quelques réflexions sur l'évolution de la fonction contrôle de gestion, Congrès AFC, $10 \mathrm{p}$.

Cotta, A. (1984). Le corporatisme. PUF Que sais-je? Paris.

Crouch, C., \& Streeck, W. (Eds.) (1996). Les capitalismes en Europe. Paris, La Découverte.

Dard, O. (1999). Jean Coutrot. De l'ingénieur au prophète. Presses Universitaires Franc-comtoises.

Desrosières, A. (1998). The politics of large numbers: A history of statistical reasoning. Cambridge, Mass: Harvard University Press (translation of La politique des grands nombres. Histoire de la raison statistique. Paris, La découverte (1993)).

Di Maggio, P. J., \& Powell, W. W. (1983). The iron cage revisited: Institutional isomorphism and collective rationality in organizational fields. American Sociological Review, 48, 147-160.

Ezzamel, M. (1994). Organizational change and accounting: Understanding the budget system in its organizational context. Organization Studies, 15, 213-240.

Fleischman, R. K., \& Tyson, T. (2007). In C. S. Chapman, A. G. Hopwood, \& M. D. Shields (Eds.). The history of management accounting in the us, handbook of management accounting research (Vol. 2, pp. 1071-1089). London: Elsevier.

Fleischman, R. K. (2000). Completing the triangle: Taylorism and the paradigms. Accounting, Auditing and Accountability Journal, 13, 597-623.

Fourquet, F. (1980). Les comptes de la puissance. Histoire de la Comptabilité Nationale et du Plan. Paris: Encres, Recherches.

Hall, P. A., \& Soskice, D. (2001). Varieties of capitalism. Oxford: Oxford University Press.

Hopwood, A. G. (1978). Towards an organizational perspective for the study of accounting and information systems. Accounting, Organizations and Society, 3(1), 3-14.

Hopwood, A. G. (1983). On trying to study accounting in the contexts in which it operates. Accounting, Organizations, and Society, 8(2/3), 287-305.

Johnson, T. H., \& Kaplan, R. S. (1987). Relevance lost - The rise and fall of management accounting. Harvard Business School Press.

Jones, T. C., \& Dugdale, D. (2002). The ABC bandwagon and the juggernaut of modernity. Accounting, Organizations and Society, 27, 121-163.

Kaplan, R. S. (1984). The evolution of management accounting. The Accounting Review, 59(3), 390-418.

Kuisel, R. (1981). Capitalism and State in modern France. Cambridge University Press (1983).

Latour, B. (1987). Science in action. Cambridge, MA: Harvard University Press.

Lemarchand, Y., \& Le Roy, F. (2000). L'introduction de la comptabilité analytique en France: de l'institutionalisation d'une pratique de gestion. Finance, Contrôle, Stratégie, 3(4), 83-111.

Lemarchand, Y. (1998). Le lieutenant-colonel Rimailho. Portait pluriel pour un itinéraire signulier. Entreprises et Histoire, 20, 9-31.

Loft, A. (1986). Towards a critical understanding of accounting: The case of cost accounting in the UK, 1914-1925. Accounting, Organizations and Society, 11(2), 137-169. 
Lordon, F. (2000). La création de valeur comme rhétorique et comme pratique. Généalogie et sociologie de la valeur actionnariale. L'année de la régulation, 4, 117-167.

Mc Arthur, J. H., \& Scott, B. R. (1970). L'industrie française face aux Plans - Harvard ausculte la France, Editions d'Organisations. Paris.

Miller, P., \& O'Leary, T. (1987). Accounting and the construction of the governable person. Accounting, Organizations and Society, 12(3), 235-265.

Miller, P., \& O'Leary, T. (1989). Hierarchies and American ideals, 1900-1940. Academy of Management Review, 14(2), 250-265.

Miller, P., \& O'Leary, T. (1994). Accounting, "Economic Citizenship" and the spatial reordering of manufacture. Accounting, Organizations and Society, 19(1), 15-43.

Miller, P., \& Rose, N. (1990). Governing economic life. Economy and Society, 19(1), 1-31.

Miller, P., \& Rose, N. (1992). Political power beyond the state: Problematics of government. British Journal of Sociology, 43(2), 173-205.

Miller, P. (1990). On the interrelations between accounting and the state. Accounting, Organizations and Society, 15(4), 315-338.

Miller, P. (1991). Accounting Innovation beyond the enterprise: Problematizing investment decisions and programming economic growth in the UK in the 1960s. Accounting, Organizations and Society, 16(8), 733-762.

Moutet, A. (1997). Les logiques de l'entreprise. Edition EHESS, Paris.

Oliver, C. (1991). Strategic responses to institutional processes. Academy of Management Review, 16, 398-427.

Parker, Lee D. (2002). 20th century textbook budgetary discourse: Formalisation, normalisation and Rebuttal in an Anglo-Saxon environment. European Accounting Review, $11,2$.

Preston, A. M., Cooper, D. J., \& Coombs, R. W. (1992). Fabricating budgets: A study of the production of management budgeting in the National Health Service. Accounting, Organizations and Society, 17, 561-593.

Puxty, A. G., Willmott, H. C., Cooper, D. J., \& Lowe, T. (1987). Modes of regulation in advanced capitalism: Locating accountancy in four countries. Accounting Organizations and Society, 12(3), 273-291.
Quail, J. M. (1996). Proprietors and managers: Structure and technique in large British enterprise 1890 to 1939, Ph.D. thesis, University of Leeds.

Ribeill, G. (2003). De La république Industrielle de Hyacinthe Dubreuil aux groupes autonomes: une vieille idée proudhonnienne sans avenir? In Georgi, F. (Ed.), Autogestion. la dernière utopie? (pp. 115-132).

Rose, N., \& Miller, P. (1992). Political power beyond the state: Problematics of government. British Journal of Sociology, 43(2), 173-205.

Scott, R. W. (1995). Institutions and organizations. Foundations for organizational science. London: Sage.

Solomons, D. (1952). The historical development of costing. In D. Solomons (Ed.), Studies in costing (pp. 1-52). London: Sweet and Maxwell.

Taboulet, H., Meyer, J., \& Sallan, A. (1966). La gestion prévisionnelle dans l'entreprise - Pratique de sa mise en place (Enquête ICG), Institut national de gestion prévisionnelle et de contrôle de gestion, Paris.

Thévenot, L. (1984). Rules and implements: Investment in forms. Social Science Information, 23(1), 1-45.

Tilly (1986). La France conteste de 1600 à nos jours. Paris: Fayard (French translation of first american edition, Harvard University Press, 1986).

Tyson, T. N. (1992). The nature ans environment of cost management among early nineteenth century US textile manufacturer. The Accounting Historians Journal, 19, 1.

Volle, M. (1977). Naissance de la statistique industrielle en France (1930-1950), Pour une Histoire de la Statistique, tome 1 (pp. 327-361). Paris, INSEE.

Walsh, E. J., \& Stewart, R. E. (1993). Accounting and the construction of institutions: The case of a factory. Accounting Organisations and Society, 18, 7/8.

Watson, T. J. (1995). Rhetoric, discourse and argument in organizational sense making: A reflexive tale. Organizational Studies, 16(5), 805-821.

Zbaracki, M. J. (1998). The rhetoric and reality of total quality management. Administrative Science Quaterly, 43, 602-636.

Zimnovitch, H. (1997). The development of standard costing at Saint-Gobain, 1920-1960: Forty years of quarantine?. Accounting Business and Financial History, 7(3), 345-365.

Zimnovitch, H. (2001). Berliet, the obstructed manager: Too clever, too soon?. Accounting Business and Financial History, 11(1), 43-58. 